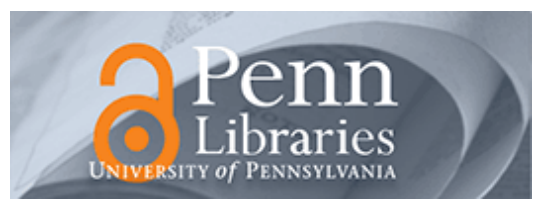

University of Pennsylvania ScholarlyCommons

June 2001

\title{
The value of paleoecology as an aid to monitoring ecosystems and landscapes, chiefly with reference to North America
}

Eville Gorham

University of Minnesota

Grace S. Brush

John Hopkins University

Lisa J. Graumlich

Montana State University

Michael L. Rosenzweig

University of Arizona

Arthur $\mathrm{H}$. Johnson

University of Pennsylvania, ahj@sas.upenn.edu

Follow this and additional works at: https://repository.upenn.edu/ees_papers

\section{Recommended Citation}

Gorham, E., Brush, G. S., Graumlich, L. J., Rosenzweig, M. L., \& Johnson, A. H. (2001). The value of paleoecology as an aid to monitoring ecosystems and landscapes, chiefly with reference to North America. Retrieved from https://repository.upenn.edu/ees_papers/14

Copyright NRC Research Press. Published in Environmental Reviews, Volume 9, Number 2, June 2001, pages 99-126.

Publisher URL: http://pubs.nrc-cnrc.gc.ca

This paper is posted at ScholarlyCommons. https://repository.upenn.edu/ees_papers/14

For more information, please contact repository@pobox.upenn.edu. 


\title{
The value of paleoecology as an aid to monitoring ecosystems and landscapes, chiefly with reference to North America
}

\author{
Abstract \\ Paleoecological indicators are examined as to their accuracy in reconstructing past biotic communities \\ and environmental conditions, their utility in answering important questions about such communities and \\ conditions, and the temporal and spatial scales over which they are effective. Next, environmental \\ problems susceptible of paleoecological analysis are considered, as are the ecosystem and landscape \\ properties that can be inferred from such an analysis. The usefulness of paleoecology in anticipating \\ ecological "surprises" is then discussed. Finally, a set of conclusions and recommendations is presented.

\section{Keywords} \\ ecosystem properties, environmental problems, surprise factor

\section{Comments} \\ Copyright NRC Research Press. Published in Environmental Reviews, Volume 9, Number 2, June 2001, \\ pages 99-126. \\ Publisher URL: http://pubs.nrc-cnrc.gc.ca
}




\title{
The value of paleoecology as an aid to monitoring ecosystems and landscapes, chiefly with reference to North America
}

\author{
Eville Gorham, Grace S. Brush, Lisa J. Graumlich, \\ Michael L. Rosenzweig, and Arthur H. Johnson
}

\begin{abstract}
Paleoecological indicators are examined as to their accuracy in reconstructing past biotic communities and environmental conditions, their utility in answering important questions about such communities and conditions, and the temporal and spatial scales over which they are effective. Next, environmental problems susceptible of paleoecological analysis are considered, as are the ecosystem and landscape properties that can be inferred from such an analysis. The usefulness of paleoecology in anticipating ecological "surprises" is then discussed. Finally, a set of conclusions and recommendations is presented.
\end{abstract}

Key words: ecosystem properties, environmental problems, surprise factor.

Résumé : Les auteurs examinent les indicateurs paléoécologiques quant à leur précision pour reconstruire les communautés biotiques et les conditions environnementales du passé, quant à leur utilité pour répondre à des questions importantes sur de telles communautés et conditions, et quant aux échelles de temps et d'espace à l'intérieur desquelles elle sont fiables. Ensuite, on considère des problèmes environnementaux se prêtant à l'analyse paléoécologique, ainsi que les propriétés des écosystèmes et des paysages qu'on peut inférer à partir de telles analyses. On discute également l'utilité de la paléoécologie pour anticiper des «surprises». On présente finalement un ensemble de conclusions et de recommandations.

Mots clés : propriétés des écosystèmes, problèmes environnementaux, facteur surprise.

[Traduit par la Rédaction]

Received March 13, 2000. Accepted March 20, 2001. Published on the NRC Research Press Web site on June 29, 2001.

E. Gorham. ${ }^{1}$ Department of Ecology, Evolution, and Behavior, University of Minnesota, Saint Paul, MN 55108, U.S.A.

G.S. Brush. Department of Geography and Environmental Engineering, The Johns Hopkins University, Baltimore, MD 21218, U.S.A.

L.J. Graumlich. Mountain Research Center, P.O. Box 174490, Montana State University, Bozeman, MT 59717, U.S.A

M.L. Rosenzweig. Department of Ecology and Evolutionary Biology, University of Arizona, Tucson, AZ 85721, U.S.A.

A.H. Johnson. Department of Geology, University of Pennsylvania, Philadelphia, PA 19104, U.S.A.

1 Corresponding author (Fax: 612-624-6777). 


\section{Introduction}

Ecosystems and landscapes are monitored over varying periods of time (though seldom beyond decades) for a variety of purposes, among them the establishment of (1) the range of natural fluctuation for some property of interest (e.g., abundance of an endangered species, soil phosphorus, surface-water alkalinity, (2) the frequency and severity of extreme events (e.g., fires, droughts, floods), (3) identifiable trends, if any, in such properties or frequencies, (4) the impact of extreme events or human impacts (through, for example, acid rain, phosphorus loading, or global warming) upon ecosystem and landscape properties, and (5) the pattern of recovery from such extreme events or human impacts. Paleoecological records often provide the only kinds of long-term background information available to interpret effectively records gathered over the short term by monitoring programs.

Paleoecology, taken here to include the disciplines of paleolimnology, paleogeochemistry, and paleoclimatology, is one of four methods of reconstructing past conditions, the others being actual historical measurements, space-for-time substitutions, and computer simulations (Charles et al. 1994). It attempts to reconstruct the nature of past plant and animal communities and their physical and chemical environments, often inferred from the kinds of communities present, and can be used to check space-for-time substitutions and hind-cast computer simulations. It is a discipline with its own scientific interest and value. Yet it has, in recent years, acquired much additional interest and value. Paleoecological studies can be used to provide long-term records of the history of communities, ecosystems, and landscapes. These, in turn, provide background data against which to assess the influence on them of a wide variety of human and natural perturbations. Such studies can be an extremely valuable complement to short-term biological and environmental monitoring of perturbations: by measuring changes in the properties of ecosystems and landscapes, by suggesting likely causes of change, and by distinguishing anthropogenic from natural causes. The application of paleolimnological approaches to biological monitoring, with much technical detail on procedures, has been described by Charles et al. (1994). The diverse technical aspects of paleoecology, and their limitations, have been treated thoroughly by Kummel and Raup (1965) and Berglund (1986).

\section{The accuracy of paleoecological reconstructions}

The accuracy with which different types of paleorecords reproduce the actual biotic communities and environmental conditions of the past is extremely variable. For instance, the pollen record in sediment cores is influenced by the great variation in pollen production and preservation among different taxa and under different environmental conditions (Birks and Birks 1980). Nevertheless, fossil pollen provides a great deal of useful paleoecological information. Cole and others have shown that pollen assemblages in sediments reflect changes on the landscape for which there are historical records. For example, Cole and Liu (1994) described from estuarine cores in California the pollen record that resulted from historical changes in vegetation. The invasion of modern grasses on the landscape is recorded in the sediments by large increases in grass pollen. Pollen of California sagebrush (Artemisia californica) increased in the sediments as sagebrush increased on the landscape with the clearing and burning of brush. Sagebrush pollen decreased as the species was grazed by introduced sheep. Likewise, deforestation is reflected by a change in the ratio of arboreal to non-arboreal pollen grains and a large increase in ragweed (Ambrosia) pollen. The ragweed horizon in most cores collected in much of North America provides a marker separating the time of more natural conditions before European settlement from anthropogenically dominated post-settlement conditions (Davis 1973; Brugam 1978; Brush 1984). Ratios of arboreal to non-arboreal pollen in sediment cores indicate the ratio of forested to non-forested land (Brush and Brush 1994).

Fossil pigments in lake sediments provide another example at the ecosystem level. Although many factors control the production and preservation of photosynthetic pigments in different groups of algae (Leavitt 1993), such pigments can be useful indicators of relative algal abundance across the broad gra- 
dient from oligotrophic to eutrophic lakes (Gorham et al. 1974). Pigments are also useful for short-term paleolimnological reconstructions in lakes whose basin morphometry and physiochemical characteristics, such as light and oxygen, are relatively constant (Leavitt and Findlay 1994).

In some circumstances, the paleorecord is highly accurate. Siliceous diatom frustules, for example, can be identified to species and are usually very well preserved in lake sediments. In laminated (varved) sediments with annual bands, therefore, an extremely precise record of diatom abundance can be obtained. Data on species tolerances for $\mathrm{pH}$, salinity, metal concentrations, etc., can be obtained from diatom assemblages in surface sediments and then used to infer, from fossil assemblages, sedimentary profiles of past $\mathrm{pH}$, salinity, and other properties by a variety of different methods (Jones et al. 1993). In the case of inferred $\mathrm{pH}$, the standard error ranges between 0.25 and 0.50 units (Charles et al. 1989).

We must, however, be careful in our interpretation of the paleorecord. According to Davis (1989a, 1991), using examples related to climate, paleoecology teaches us five lessons concerning ecosystem responses to environmental change.

- Species respond individualistically to changing environments. For instance, combinations of species different from those that we now see together occurred in the past, when the climate was very different (Davis 1981a; Webb 1987).

- Biological responses often involve a time lag, which differs with each species. Aquatic beetles, for example, colonized Windermere in the English Lake District soon after the climate warmed in the early postglacial period, but birch trees colonized the soils developing in the surrounding landscape much more slowly, lagging about 500 years behind the beetles (Pennington 1986). One might expect that, in general, small species with short life cycles are likely to respond to disturbance more rapidly than large species with long life cycles.

- Disturbance regimes change along with changing climate. Fire, for instance, declined in importance as climate became more mesic in the White Mountains of New Hampshire 7000 years ago (Davis 1985).

- Human land use, particularly for agriculture, can have greater local impacts upon landscapes than climatic change.

- Multiple impacts are occurring that will cause effects different from those seen in the paleorecord. The increasing exposure of present-day ecosystems to climatic warming, ultraviolet radiation, and acid deposition coupled with the deposition of nitrogen, a nutrient often limiting plant growth, is likely to result in new assemblages of species.

Individual paleoecological techniques also have their limitations. For instance, pollen grains are seldom identifiable to species, and as one goes back in time pollen assemblages may not resemble those representative of modern vegetation. According to Hunter et al. (1988) most modern plant communities in North America do not exceed 8000 years in age and are "transitory assemblages ... that have changed in abundance, distribution, and association in response to the large climatic changes of the past 20,000 years." As another example, many species persist long after changes in the environment have made it impossible for them to colonize and establish themselves (Gorham 1957), which may lessen their value as indicators of environmental conditions. Because of their long lives, lags in the responses of tree species to environmental change may be especially important (Davis 1989a, 1989b). Diagenetic processes in sediments may alter the nature and distribution of their chemical components, which may also be affected by erosion and slumping within basins. 


\section{The utility of paleoecological studies}

As adjuncts to short-term monitoring programs, paleoecological studies can answer five main questions.

What were the properties of communities, ecosystems, and landscapes prior to or following natural or human disturbances?

Let us consider evidence from fossil pollen and seeds. Seed and pollen profiles, compiled from areas of high sedimentation, contribute histories of local conditions at fine temporal resolutions ranging from annual to decadal. In rare cases, seasonal changes may also be detected. The best records are derived from cores of varved sediments in lakes where each varve represents 1 year (Swain 1973; McAndrews and Boyko-Diakonow 1989). Other areas of high deposition, such as marshes (Orson et al. 1992; Khan and Brush 1994), small lakes (Davis 1985), and upper estuaries (Brush 1986), also provide annual to decadal histories. These records show natural variations in the properties of communities, ecosystems, and landscapes that occur during periods of similar climate, at high time resolutions. The following are some examples of information contained in these records that would be useful for monitoring programs.

Climate changes can be very abrupt and do not necessarily last for a long time. Many cores of lake sediments from North America and Europe show an increase in pollen of species representing colder climates and a decrease in species of warmer climates about 12500 years ago. This sudden reversal from a warmer to a cooler climate was recognized by increases in pollen of colder and drier taxa in lake sediments and by geochemical changes including increased amounts of soil particles in ice cores. It lasted about 1000-1500 years and ended as abruptly as it began (Björck 1996). Pollen and seed records also show the rapidity and nature of change in vegetation that accompanied the approximate 200-year Medieval Warm Period that began about 1000 years ago and was followed by a period of rapid cooling referred to as the Little Ice Age (Gajewski 1987). The rapidity of the vegetation response to late Holocene climatic change is supported by multiple proxy indicators, including geochemical and limnological variables (Battarbee 2000).

Although pollen records from lake sediments are usually employed to reconstruct vegetation at the landscape scale, recent studies indicate that records from peaty deposits in forest hollows can reflect vegetation at the local ecosystem level (Sugita 1998; Davis 2000).

In some lakes, analysis of sediment grain size in dated cores can also provide clues to climatic change, because it reflects fluctuations of inlet and outlet discharge (Campbell 1998). The record of grain size may, therefore, proxy for past changes in climate that are connected to the excess of precipitation over evaporation.

Tree rings are also extremely useful in establishing the nature of past climates. The amount of wood allocated to each annual ring results from an integration of the internal carbon requirements of a tree (for respiration, reproduction, growth, defense, and repair) and its response to growth-influencing environmental factors such as light, temperature, moisture, and injury. Commonly, year-to-year differences in weather conditions dominate the high-frequency variance in ring widths. In these cases physiologically meaningful, temporally stable relationships between tree-ring width and monthly temperature and (or) precipitation values can be determined using widely accepted cross-dating, indexing, statistical, and verification procedures (e.g., Fritts 1976; Cook and Peters 1981; Cook 1987). These are then used to indicate climatic conditions outside the period of instrumental records. Recently, long-term (centuries to millennia) reconstruction of temperatures from tree rings, combined in some cases with other annually resolved proxies, has contributed high-resolution records of the magnitude and regional distribution of terrestrial warming (Cook et al. 1991; D'Arrigo and Jacoby 1993; Lara and Villalba 1993; Luckman et al. 1997; Mann et al. 1998, 1999; Briffa 2000).

Although most common applications of tree-ring patterns use long-term stable relationships between temperature or rainfall and standardized ring widths to estimate weather conditions of the past, there 
are other ways in which they may be used as indicators. For instance, abrupt changes in tree-ringweather relationships can signal the onset of physiological response to stress, as demonstrated for red spruce (Picea rubens) growing in the montane forests of New York and New England (e.g., Cook 1987; Johnson et al. 1988; Tobi et al. 1995). Beginning about 1960, red spruce at high elevations shifted their normal carbon allocation patterns, using carbon for defense and repair rather than for producing stem wood. Two decades of altered carbon-allocation patterns identified by those tree-ring anomalies were accompanied by regional mortality as trees were weakened, primarily by foliar freezing injury resulting from acid cloudwater damage to cell membranes and secondarily from a variety of natural pathogens (Johnson 1992; Wargo et al. 1993; DeHayes et al. 1999). Although tree-ring anomalies are not expected to offer much evidence about causal factors (e.g., Cook 1987), they do identify critical intervals of time, thus helping to constrain the search for causes.

Fire scars, in combination with annual growth increments (rings) in forest trees, have been particularly important for documenting the pattern and frequency of fire as an agent of disturbance before active exclusion of fire from forests during the 20th century. In the Boundary Waters Wilderness of Minnesota, for example, Heinselman (1996) established both the frequency of fires and the size of the area burned over a period of four centuries. Intervals between the nine major fires from 1681 to 1894 , which accounted for $82 \%$ of the burned area, ranged from 11 to 42 years and averaged 27 years.

Fire and storms are also represented in sediment cores by charcoal and high sediment influxes. The responses of vegetation to those changes are represented by pollen grains (and in some cases seeds) preserved in the same sediment layers that contain charcoal and represent high sediment influxes. Clark (1988) showed higher charcoal frequencies in sediments from northwestern Minnesota during climatically warm intervals, determined from the pollen taxa, than during colder times. Yuan (1995) showed high charcoal in estuarine sediments from a tributary of the Chesapeake Bay during a period when oak and herbaceous pollen, characteristic of a warmer climate, replaced hemlock pollen.

When combined with estimates of paleoclimatic fluctuations, fire histories give insights into the nature of fire and climate interactions. In western North America detailed records of spatial and temporal patterns of fire extend back for up to 2000 years and demonstrate the strong coupling between climatic fluctuations and wildland fire. A 2000-year record of fire and independent records of paleoclimate in the Sierra Nevada indicate that regionally synchronous fire occurrence was inversely related to yearly fluctuations in precipitation and directly related to decadal to centennial variations in temperature (Swetnam 1993). Similarly, in the southwestern United States a 300-year record of the area of forests burned annually indicates that fires were less widespread during El Niño events and were more widespread during La Niña years. These phenomena were measured as the December-February Southern Oscillation Index, which also correlated with spring precipitation in Arizona and New Mexico and August-February precipitation over the Line Islands in the Central Pacific Ocean (Swetnam and Betancourt 1990). There are other correlates independent of the tree-ring records, including historical records from tropical Pacific fisheries and records from the Quelcaya ice core (see Philander 1990).

\section{What has been the pattern of recovery from disturbance, and was the prior state reestablished?}

Again, pollen grains, which provide a history of successional changes after disturbance, can provide answers. The disappearance of hemlock (Tsuga canadensis) pollen from the fossil record about 4800 years ago has been attributed to pathology because hemlock pollen disappeared at about the same time throughout its range in eastern North America (Davis 1981b). Recently, abundant remnants of defoliating phytophagous insects have been found fossilized with chewed hemlock needles in Canada, coincident with the hemlock decline (Bhiry and Filion 1996). Hemlock then took many centuries to re-emerge from near-extinction and recover its frequency in the fossil record. More recently, American chestnut (Castanea dentata) and American elm (Ulmus americana) have been all but eliminated by disease, 
Fig. 1. Reconstructed surface-water $\mathrm{pH}$ of Baby Lake near Sudbury, based on inferences from assemblages of diatoms and chrysophytes in a dated core of sediment and with a comparison of recent $\mathrm{pH}$ measurements. (Reprinted with kind permission of Kluwer Academic Publishers from A.S. Dixit, S.S. Dixit, and J.P. Smol, Water, Air and Soil Pollution, vol. 62, p. 81, Fig. 4, copyright 1992.)

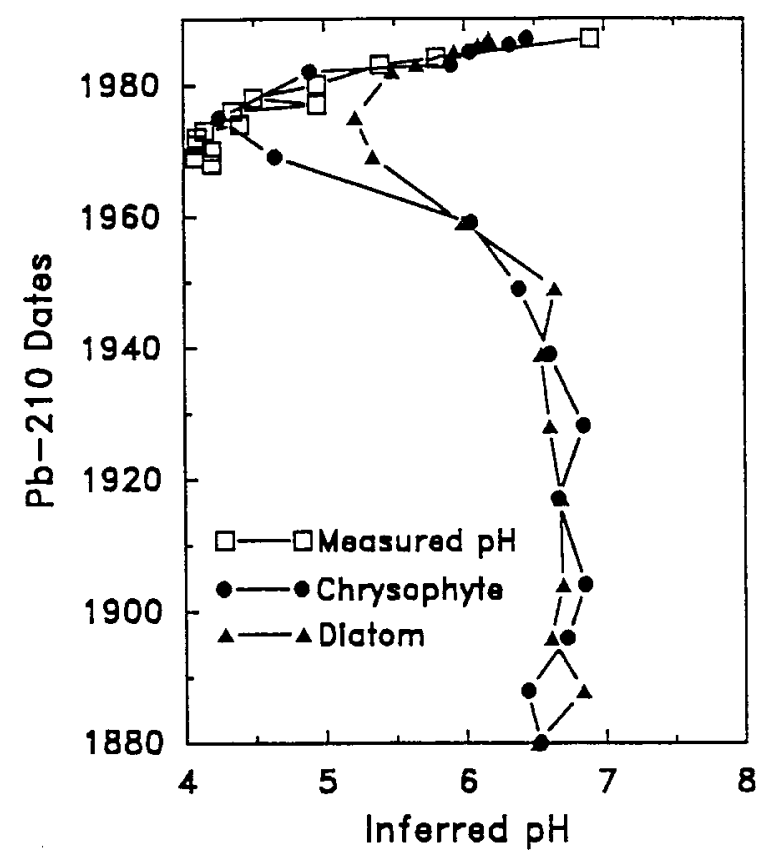

causing a sharp decline in pollen. The chestnut blight, a fungal pathogen, destroyed most chestnut trees by 1930 . This event is recorded in the fossil-pollen record by a decline in chestnut pollen about 1920 and the absence of chestnut pollen after 1930 (Anderson 1974). The characteristics of the chestnut pollen decline resemble those of the hemlock decline. Insect attacks also cause characteristic changes in the growth rings of trees (Brubaker and Greene 1980).

Based on pollen records, Foster (1995) found that the forests in central Massachusetts are not returning to their pre-settlement composition. He speculates that this may be due to various kinds of land use, including continued selective cutting, that have kept the forests in an early stage of succession.

On shorter time scales, recovery of lakes from the effects of acid deposition has been demonstrated in several regions by algal-based profiles of inferred $\mathrm{pH}$. A particularly clear case is that of Baby Lake, Sudbury, Ontario. There, the effects of severe smelter pollution have been substantially reversed following major reductions in the emission of sulfur dioxide (Dixit et al. 1992), and chrysophyteinferred $\mathrm{pH}$ follows closely the measured values from the late 1960s to the mid-1980s (Fig. 1). A recent downturn in certain air pollutants in South Sweden has been shown by a decrease in the deposition to lake sediments of carbonaceous fly-ash particles, which are produced by the combustion of fossil fuels. Wik and Renberg (1996) reported peaks in the rates of sedimentation of such particles into lakes in the 1970 s, followed by a modest decline to the present.

Paleogeochemistry is also useful. For example, Norton et al. (1997) were able to demonstrate an acceleration of lead accumulation by bog peat and pond sediment in Maine from the late 19th century until very recently. Then, the phase-out of leaded gasoline caused the rate of accumulation to decline (Fig. 2). Similarly, Rapaport and Eisenreich (1986) were able to develop input functions (fraction of total input versus time) for DDT and toxaphene from their rates of accumulation in four dated North American peat cores (Fig. 3). Each showed a very clear pattern of increasing and then decreasing use. 
Fig. 2. Rates of accumulation of lead in a dated sediment core from Sargent Mountain Pond (SMP) and in two dated peat cores from a hummock in Big Heath Bog (BH 1 and 2), Maine. (Reprinted with kind permission of Kluwer Academic Publishers from S.A. Norton, G.C. Evans, and J.S. Kahl, Water, Air and Soil Pollution, vol. 100, p. 279, Fig. 3, copyright 1997.)

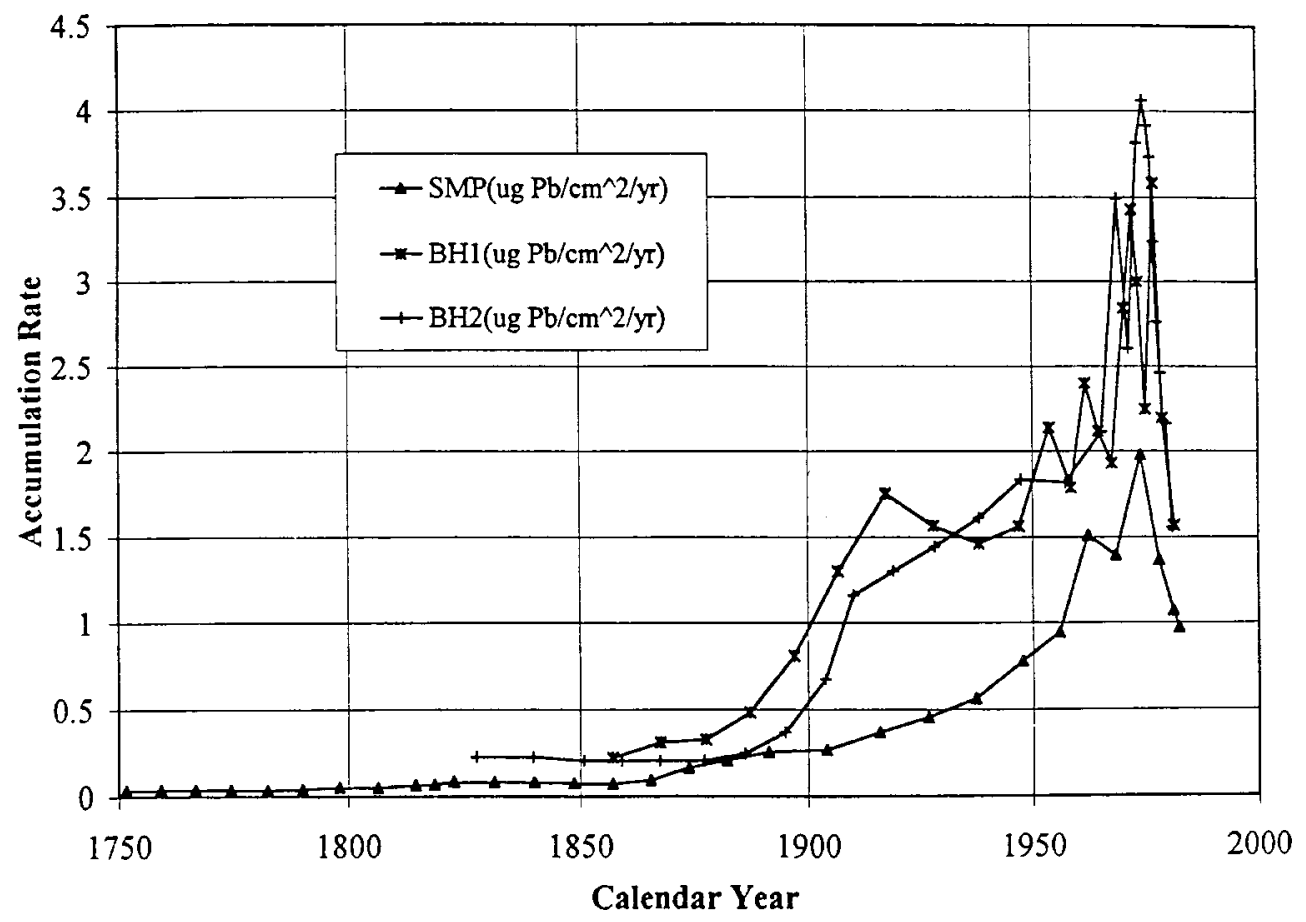

\section{What is the nature and magnitude of natural variability, and the frequency of unusually extreme conditions?}

The vegetational history of many parts of North America has been reconstructed (COHMAP Members 1988) from pollen profiles that span the last 10000 to 40000 years on century-to-millennium scales. These pollen profiles provide records of vegetation during periods of major climate change when the continent was under maximum glaciation and since the ice sheet retreated to its present configuration. Table 1 is a summary of vegetational changes through Holocene time along the east coast of the U.S.A. These data furnish the long-term historical context within which more detailed records of shorter time periods can be compared. They are also useful in studying the response of vegetation to soil weathering and acidification, nutrient cycling, and other slow processes for which no other data exist.

At finer temporal and spatial time scales, the history of forest landscapes can be inferred from treering based reconstructions of population dynamics resolved at decade-to-century time scales. Long-term patterns and rates of change can be particularly useful for interpreting whether recent fluctuations represent changes that are outside the envelope of "natural" variability. For example, seedling establishment above the current limit of adult tree growth has been observed at treeline at both arctic and alpine sites (Graumlich 1994) and has been interpreted as an indication of climate warming. In regions where long-term data on population dynamics exist, changes in treeline and in seedling establishment often appear as a response to changes in climate conditions (LaMarche and Mooney 1967; Lloyd and Graumlich 1997; Kullman 1995). Studies such as those cited provide valuable insights into species-specific responses to critical climate variables.

Fish scales, when present in sediments, are particularly useful for reconstructing records of the population sizes of some species of fish. Soutar and Isaacs (1974) used scales of several pelagic species 
Fig. 3. Input functions (fractions of total input versus time) for toxaphene and DDT, derived from their rates of accumulation in dated North American peat cores. (Reprinted from Fig. 7 in Atmospheric Environment, vol. 20, R. Rapaport and S.J. Eisenreich, Atmospheric deposition of toxaphene to eastern North America derived from peat accumulation, pp. 2367-2379, copyright 1986, with permission from Elsevier Science.)

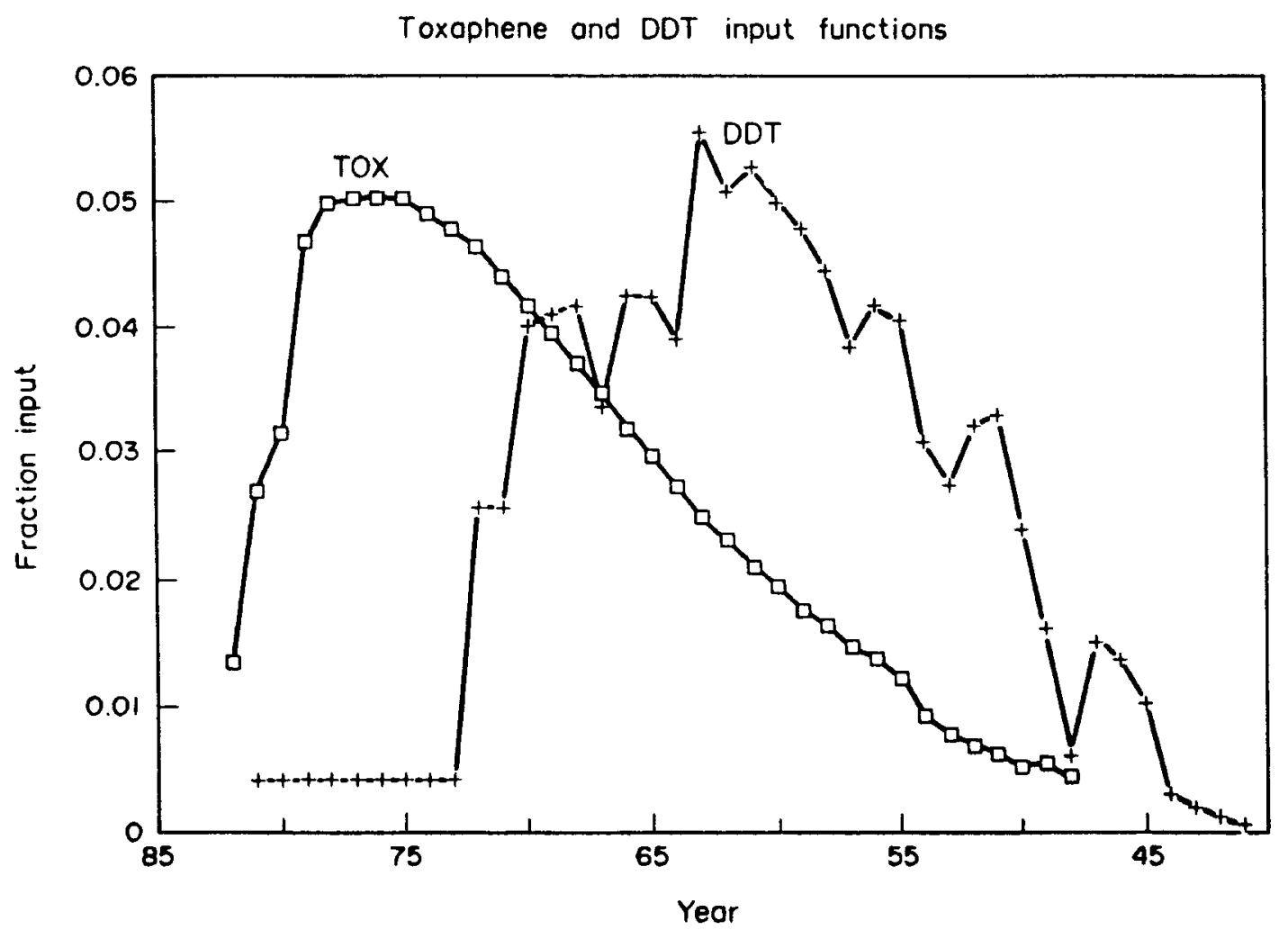

in sediments off the coast of California to track changes in their populations from 1925 to 1970 . Then they compared this period to the record of the period before 1925. They found a very high consistency between historical estimates of pelagic fish populations and scale deposition for a similar period. Over the longer term of two millennia Soutar and Isaacs (1969) examined scales of Sardinops caerulea (Pacific sardine) at 10-year intervals and found marked fluctuations throughout the period (Fig. 4). These longterm irregularities in population size show that the substantial changes in sardine populations during the 20th century may not have arisen solely from anthropogenic disturbance. Recently, $\delta{ }^{15} \mathrm{~N}$ in lake sediments has been used as a proxy, with other paleorecords, for the abundance of Pacific salmon over the past 300 years (Finney et al. 2000). Fish scales are also present in the sediments of freshwater lakes (Peteet et al. 1993).

As to the frequency of extreme conditions, Heinselman's (1996) account of the history of the Boundary Waters Wilderness, mentioned above, provides an excellent example.

\section{Were communities and ecosystems relatively stable prior to disturbance, or were there significant trends or fluctuations in some of their properties?}

The vegetational history of postglacial North America, mentioned in the previous section, provides evidence over the long term in answer to this question. Close-interval sampling where annually varved lake sediments are available can provide evidence on both long and very short time-scales (Bradbury and Dean 1993). 


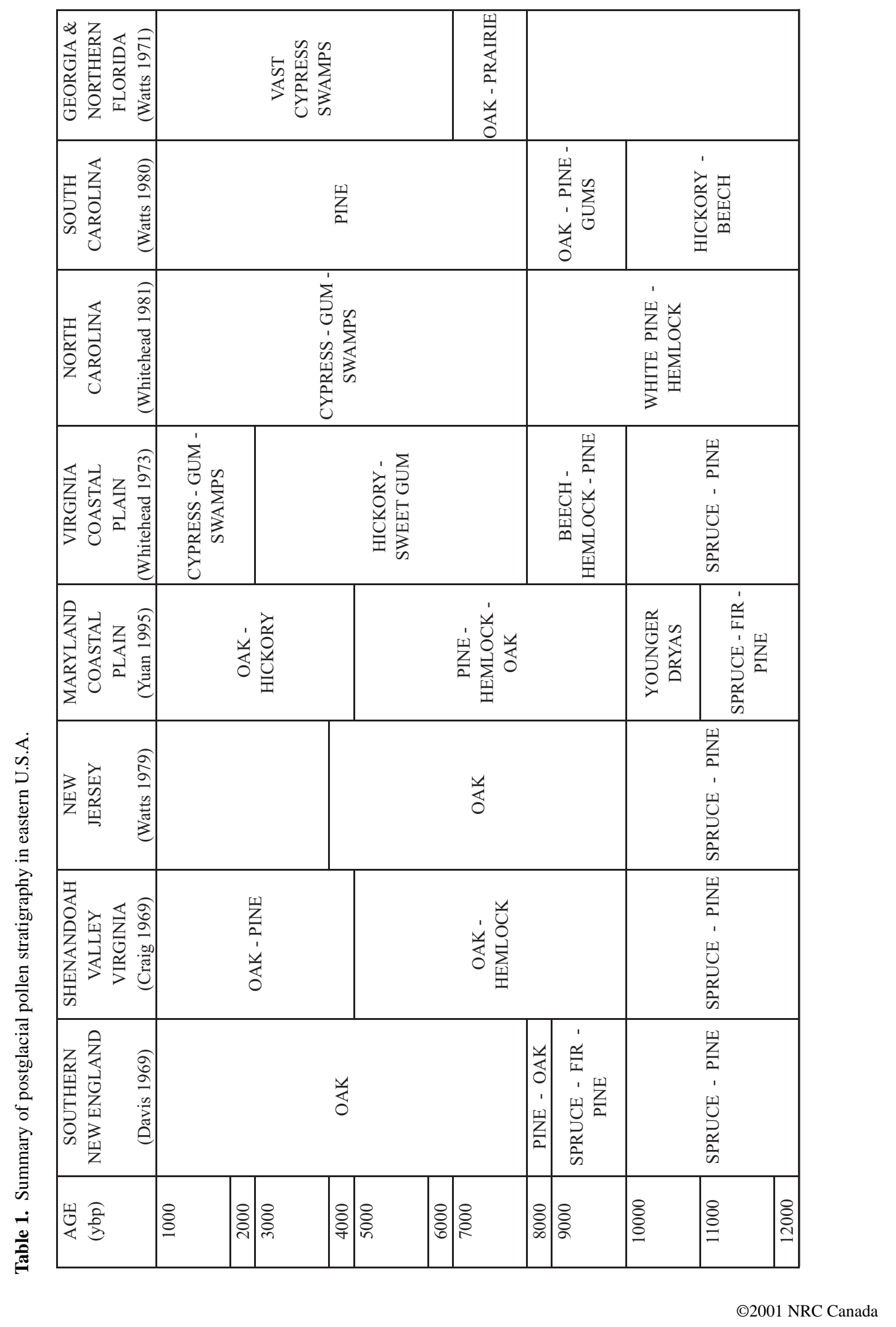


Fig. 4. Population of the Pacific sardine, inferred from the density of fish scales in a dated sediment core. (Modified from Soutar and Isaacs (1969).)

\section{Pacific sardine}

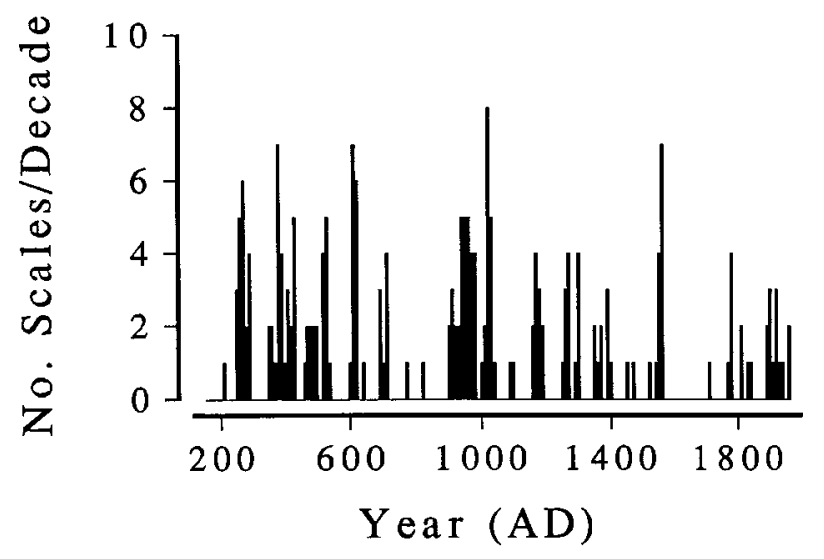

An excellent paleolimnological example of past trends is provided by Lilla Öresjön, a lake in southwestern Sweden studied by Renberg (1990). His reconstruction (Fig. 5) of inferred pH values, based on diatom assemblages in a dated sediment core, showed a slow trend of natural acidification from $\mathrm{pH}$ above 7 to $\mathrm{pH} 5.2$ - between 12600 and 2300 B.P. Then, human settlement and land clearance led to the leaching of bases into the lake from surrounding soils and a rise in $\mathrm{pH}$ to 6.3. Beginning about a century ago, a second trend of acidification, attributable to acid deposition, led $\mathrm{pH}$ to decline to about 4.5, well below its previous low value, by the 1960s.

Paleoecological studies sometimes reveal relatively sudden transitions from one stable state to another, in peatlands, for instance, the shift from circumneutral fen to strongly acid bog. In the Red Lake Peatland of Minnesota, Gorham and Janssens (1992a, see also Janssens et al. 1992 and Gorham and Janssens 1992b) were able to show, through analysis of bryophyte fossils, that a sedge-dominated fen community stable for about 1000 years after 3300 B.P. changed quite suddenly - in less, and perhaps much less, than 200 years - into a Sphagnum-dominated community that has persisted until the present (Fig. 6). The Sphagnum community actually exists as a bog "island" of several square kilometres between fen water-tracks, and its present margin has shifted back and forth from fen to bog three times, depending presumably on the rate of climate-driven upwelling of ground-water into the water tracks. A useful indicator of the transitional state is the bog moss Sphagnum subsecundum (Gorham and Janssens 1992b). Diagrams of the kind shown in Fig. 6 are significant for another reason; they provide baselines against which to assess whether anthropogenic disturbances such as acid deposition and climate warming have forced (or will force in the future) these peatland ecosystems beyond the limits of acidity and water-table depth experienced over centuries to millennia in the past.

\section{Do anthropogenic disturbances have effects that are different in degree or kind from those of natural disturbances?}

The answer to this question can be yes, in certain circumstances. In Lilla Öresjön, for example, the degree of anthropogenic acidification has exceeded considerably the natural acidification of the more remote past (Renberg 1990). As to differences in kind, agricultural and forestry activities clearly bring about sustained alterations in communities and ecosystems. A quite different example is provided by eggshell thinning in raptorial birds (Fig. 7) owing to their exposure to chlorinated hydrocarbons produced 
Fig. 5. Hustedt $\mathrm{pH}$ categories, diatom-inferred $\mathrm{pH}$ values (weighted averaging), calibrated radiocarbon dates, ${ }^{210} \mathrm{~Pb}$ dates, and $\mathrm{pH}$ periods in the history of Lilla Öresjön, southwest Sweden. (Reprinted with kind permission of the Royal Society from I. Renberg, Philosophical Transactions of the Royal Society of London B, vol. 327, p. 359, Fig. 7, 1990.)

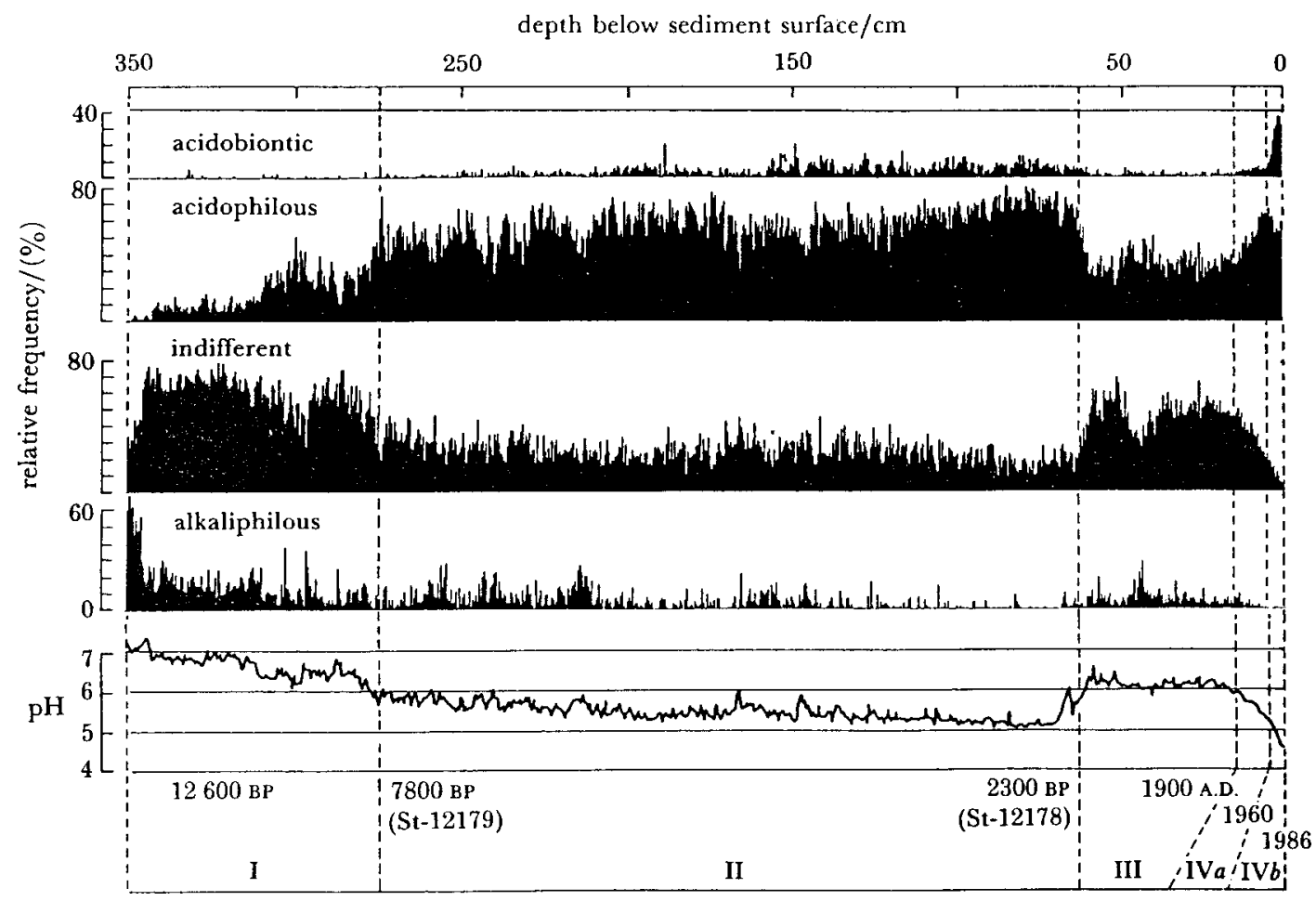

for human uses (Ratcliffe 1967). This phenomenon was documented using museum collections of birds' eggs to determine past eggshell thickness. It appears to have no analog in environments not seriously polluted by these agricultural and industrial compounds.

\section{Questions of scale}

Paleoecological analyses are useful over a wide range of scales, both spatial and temporal. For instance, pollen diagrams from lake sediments represent an area extending one to several kilometres from the coring site, depending on the topography of the region and the degree of deforestation (Bradshaw and Webb 1985). Pollen from sediment cores in forest hollows can allow more local reconstructions of stand histories (Calcote 1998). Seed profiles generally represent an area extending only a few metres from the coring site (Jackson et al. 1997). In connection with spatial analyses, it must be recognized that certain geographic areas are more sensitive to environmental changes than others, whether these changes are natural or anthropogenic. For example, vegetation of sandy coastal areas and marshes with fluctuating water levels is much more sensitive to climatic and geomorphic changes than inland Piedmont areas underlain by thick saprolitic soils rich in clay and therefore of high water-holding capacity. Similarly, acid rain has little effect on lakes lying on thick soils in calcareous terrain, but profound effects where the soils are thin, coarse, and derived from granites and quartzites.

The temporal resolution of a sediment core is determined by the sedimentation rate. Three scales of resolution are evident: (1) the millennial time scale, which gives the broad changes in vegetation related to climate; (2) the decade-to-century scale, which gives the responses to geomorphic and land-use 
Fig. 6. Selected profiles versus calendar-year age for analyses from peat cores RLP8112 (A) and RLP8104 (B) in the Red Lake Peatland of northern Minnesota. (Modified, with permission, from two figures in Janssens et al. (1992).)



changes, for instance the responses of riparian vegetation and soil erosion to changes in river channels; and (3) the annual and seasonal scales, which give the responses to weather and biological factors, an example being the effects of changes in precipitation and flooding regime on the ability of species to germinate.

Studies of fossil pollen have been applied spatially both to the reconstruction of postglacial changes in regional patterns of vegetation across eastern North American (Overpeck et al. 1991) and to very local changes in patch dynamics within hemlock-hardwood forests of the Upper Peninsula of Michigan (Davis et al. 1994). Temporal applications have ranged even more widely, from studies of annually varved lake sediments that reveal changes from year to year, and in some cases from one season to another (Leavitt and Findlay 1994), to studies over the geological time scale of the origin and evolution of life and its biogeochemical consequences (Gorham 1991). Paleoatmospheric signatures of atmospheric carbon dioxide in Neogene fossil oak leaves, through their stomatal frequencies (Van Der Burgh et al. 1993), provide an example on an intermediate time scale (10 Ma).

Using remains of invertebrate animals, including the Cladoceran Bosmina, chydorids, chironomids, and the phantom-midge larva Chaoborus in core samples, Hofmann (1978) showed that the species in the Grosser Segeberger See changed as the lake progressed from late glacial time, when cold climatic conditions controlled species, to about 5000 years ago, when the water was still clear. Eutrophication 
Fig. 6. (concluded).

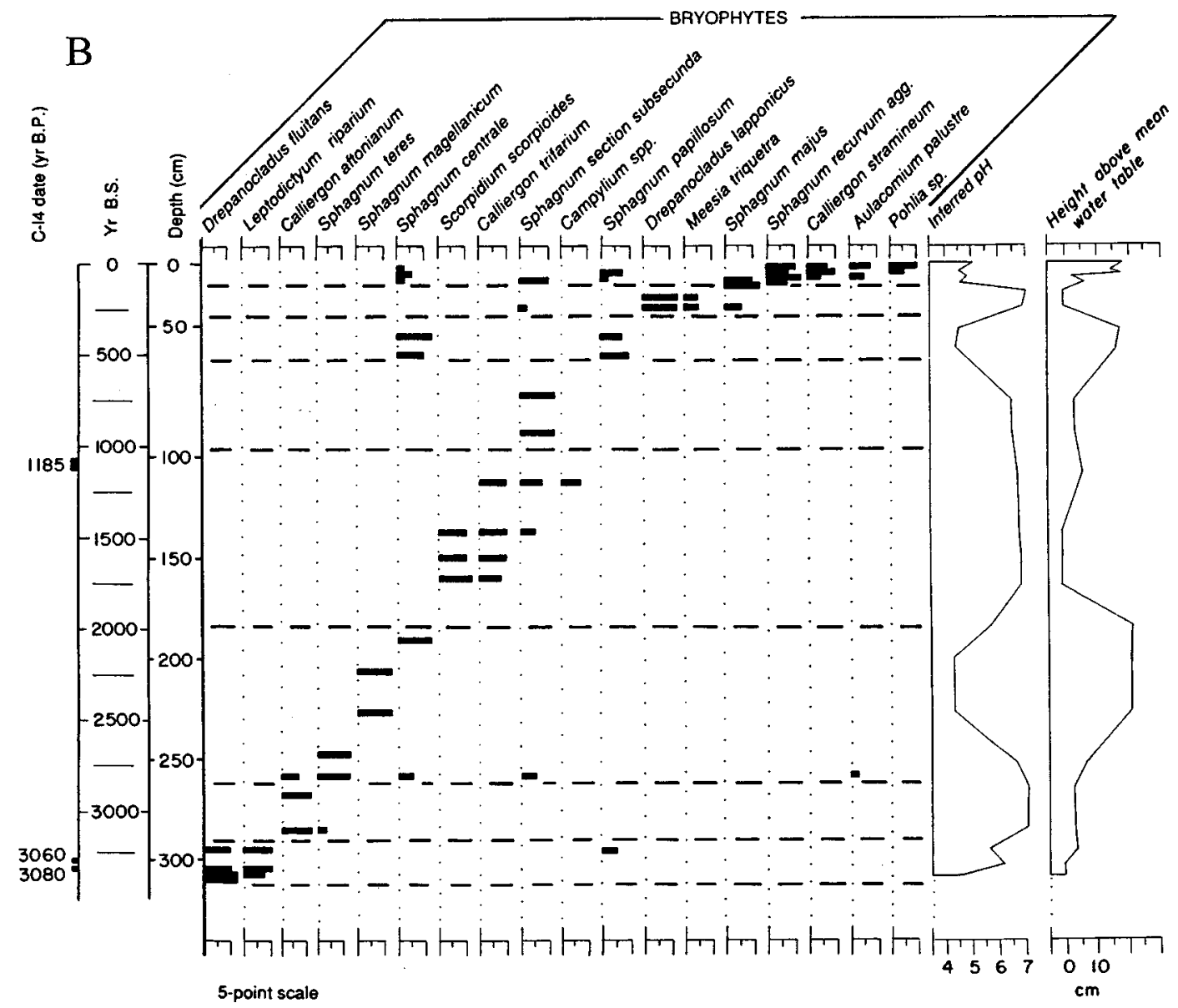

then increased to a final stage with blue-green algae blooms. On a historic time scale, Kansanen (1985) used midge fauna in lake sediments to reconstruct the change from oliogotrophic to eutrophic states in Lake Vanajavesi in southern Finland and to assess the oxygen state of the lake. Midges are particularly good indicators of environmental conditions because the species respond quickly to environmental changes and are particularly sensitive to water quality, including the amount of oxygen in the water. Dormant bacteria can be useful paleoindicators for the influence of sewage and of agricultural activity upon lakes (Renberg and Nilsson 1992).

\section{Paleoecological analysis of environmental problems}

Most, if not all, environmental problems can be studied from a paleoecological perspective to determine whether trends subsequent to anthropogenic disturbance fall outside the range of natural variability and can therefore be ascribed plausibly to such disturbance. Here we discuss several examples of great current concern.

Climate change has long been a subject of paleoecological investigation, dating back at least to DeLuc's observations of peat stratigraphy in Germany, cited by Rennie (1807). De Luc recognized that dry summers favor the growth of woody plants and produce a hard black peat, whereas wet summers favor aquatic plants, which form a soft spongy peat dominated by moss remains. Thus, "he could even 
Fig. 7. Change in the ratio of weight to size (thickness) in eggshells of the British peregrine falcon (above) and sparrowhawk (below). For falcons, circles represent eggshells from the Scottish Highlands and dots represent eggshells from other districts. For sparrowhawks, circles represent eggshells from southeastern England and dots represent eggshells from other districts. (Reprinted with permission from D.A. Ratcliffe and Nature (London), vol. 215, p. 209, Figs 1 and 2, copyright 1967 Macmillan Magazines Ltd.)
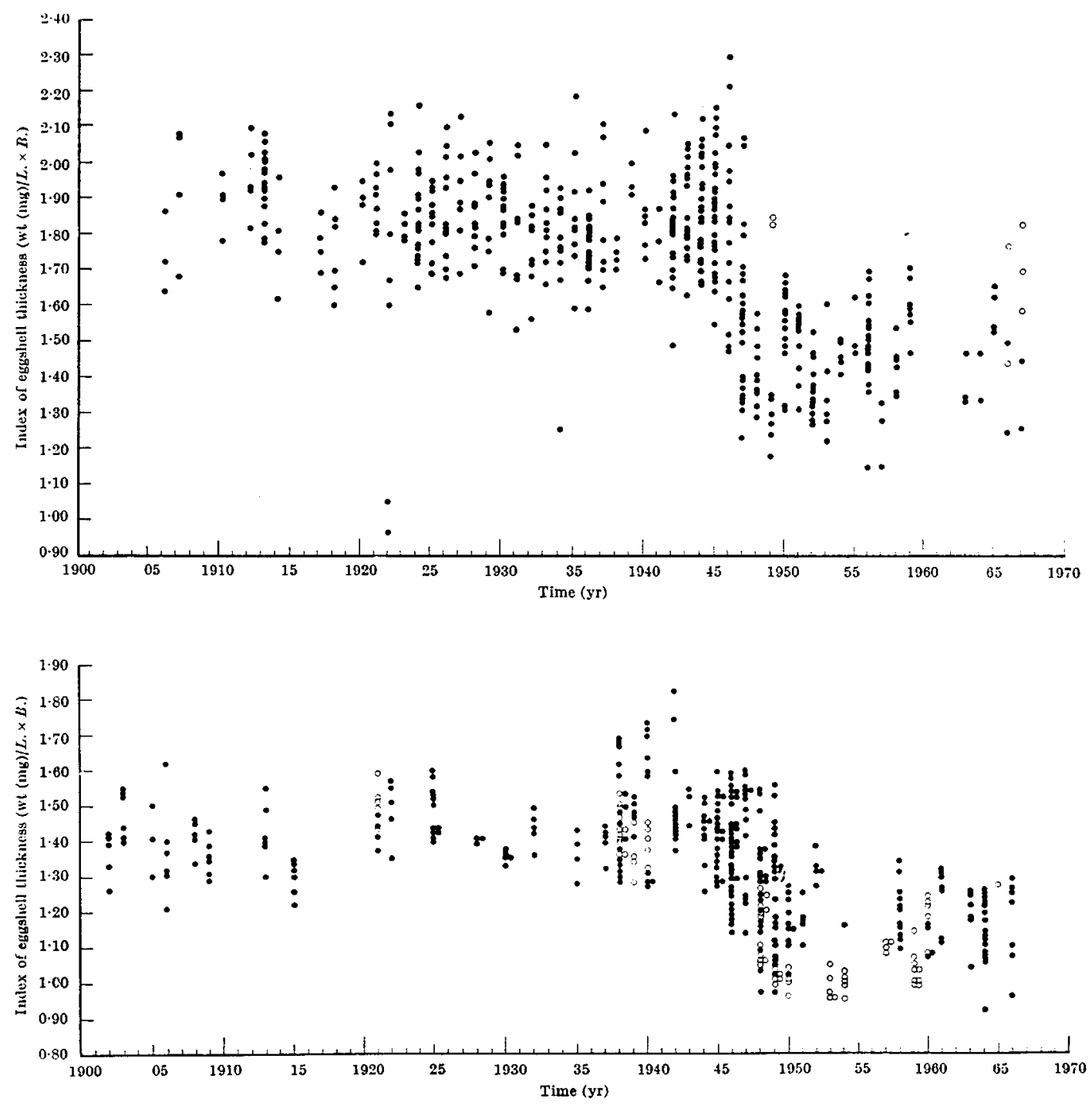

distinguish by this means, the different produce of a wet and dry season, from the residuum each had left ... ." Since that time a vast literature has accumulated on paleoclimatic inferences from a variety of dated proxy records that include, among many others, tree rings and fossil assemblages of pollen, diatoms, ostracods, and foraminifera in cores of lake and ocean sediments (Gates et al. 1975; Smol et al. 1991; Charles et al. 1994; Schwalb et al. 1995).

The effect of acid deposition upon lakes has already been mentioned in connection with changes in the Swedish lake Lilla Öresjön. Cultural eutrophication provides another paleolimnological example, for instance in Harvey's Lake, Vermont (Engstrom et al. 1985). There, stratigraphic analyses of inorganic 
Fig. 8. Pigments in the Harvey's Lake sediment core calculated as concentration (above) and accumulation rate (below), except as noted. O.M. = organic matter. Units for blue-green algal pigments are $\mu \mathrm{g}$ and for chlorophyll and carotenoids are standard absorbance units. (Reprinted with permission of Blackwell Scientific Publications from D.R. Engstrom, E.B. Swain, and J.C. Kingston, Freshwater Biology, vol. 15, p. 275, Fig. 8, 1985.)
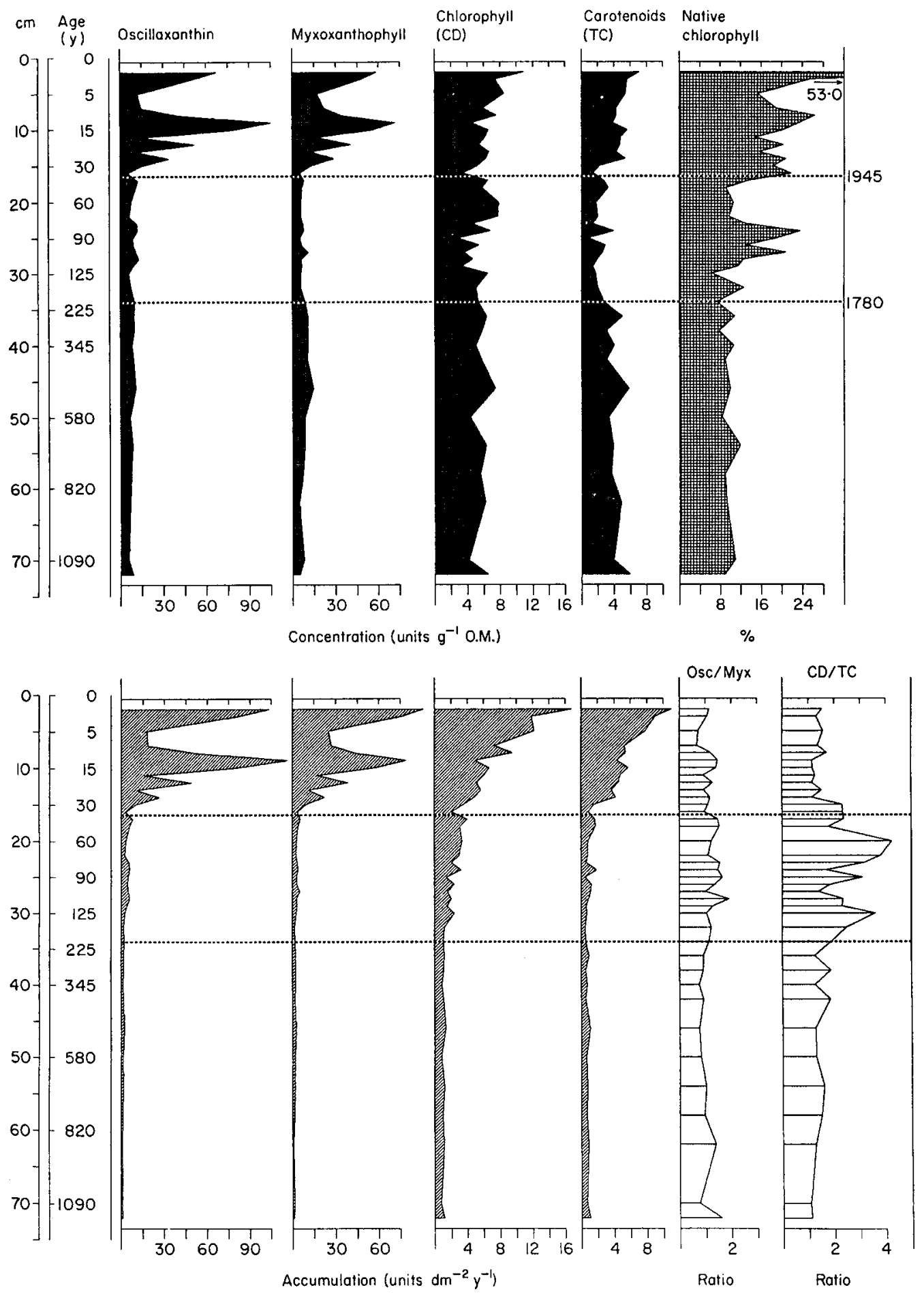

(C)2001 NRC Canada 
chemistry, fossil pigments and fossil diatoms in a core of profundal sediments (Fig. 8) demonstrated clearly the influence, after 1780, of nutrient enrichment owing to European settlement and, after 1945, shoreline development and dairying in the catchment. The result of initial settlement was an increase in primary productivity, but it was only after 1945 that the fossil pigments oscillaxanthin and myxoxanthophyll, characteristic of blue-green algae, increased markedly in abundance. Both of the studies mentioned above documented major changes in the species composition of the phytoplankton.

As regards biodiversity, recent paleoecological research indicates — contrary to earlier views that it may not have increased much over geologic time, except during the colonization of new habitats or after mass extinctions (Rosenzweig 1996). Coupled with the well-known relationship of species diversity to area (e.g., Tiffney and Niklas 1990), this suggests that human activities leading to extensive reductions in areas reserved for more or less natural biotic communities are likely to cause massive reductions in biodiversity, dooming current conservation tactics largely to failure and calling out for new approaches. Paleoecologists Martin (1984) and Flannery (1994) have already identified a major decline in the diversity of large mammals and birds over the past 100000 years owing to modest improvements in hunting methods, and a massive extinction of plants and birds accompanied the settlement of Pacific cultures in Micronesia, Melanesia, and Polynesia over the past several thousand years (Steadman 1993). On a more local scale, Odgaard (1994) used pollen analysis to suggest that since 4000 B.C. in West Jutland, Denmark, intermediate fire intensity (estimated from particles of charcoal and assumed to be primarily anthropogenic in origin) maximized floristic diversity at the landscape scale as compared with periods of greater or lesser fire intensity.

Paleoecological records also show loss of species richness associated with eutrophication and pollution in aquatic communities. For example, Stockner and Benson (1967) showed that the succession of diatom assemblages in Lake Washington decreased in species numbers with eutrophication. More recently, Cooper (1995) showed a pronounced decrease of diatom species in the Chesapeake Bay beginning with agriculture after European settlement. During this time the diatom population converted from a predominantly rich benthic community to one which today consists of a much poorer assemblage, $95 \%$ of which is made up of one very small planktonic species. The change in species richness coincided with $25 \%$ deforestation of the watershed, at which time nitrogen influxes into the sediment also increased (Cooper and Brush 1991).

Brush and Hilgartner (2000) analyzed seeds of submerged macrophytes in sediment cores collected in 12 Chesapeake Bay tributaries. In this case local extinctions of all macrophyte species occurred twice over a 2000-year period. The first time was in the early 1900s, in a tributary where the Baltimore Waste Water Treatment Plant began to discharge sewage in 1907. The second set of local extinctions occurred in the 1970s in all of the tributaries of the Chesapeake, coinciding with historical records of the loss of submerged macrophytes in the estuary. The later extinctions were preceded by reductions in macrophyte abundance, beginning with deforestation and resulting erosion and sedimentation in the 18th century.

Human activity does not always reduce biodiversity. Lake acidification appears to have increased diversity in the chrysophyte algae of many lakes (Smol 1995).

Analyzing species richness from paleoecological studies requires that the time interval for each subsample of the sediment core be measured (Smol 1981). Alternatively, the number of species may be recorded for equal time intervals. Although this can be accomplished most easily in varved sediments, it is also possible in other sediments if sedimentation rates can be calculated by dating core samples.

\section{Summary of ecosystem properties inferred from paleoecological indicators}

As mentioned above, paleoecology can be used to infer changes in a great variety of ecosystem characteristics, whether physical, chemical, or biological. Examples already mentioned include species composition, productivity, climate, soil weathering, nutrient enrichment, acidity, trace-metal and traceorganic accumulation, fire history, the dynamics (or stability) of communities and environments, and 
biodiversity. Table 2 provides examples of numerous paleoecological indicators, what they indicate, the scales at which they are relevant, and their limitations. Many more ecosystem characteristics and their indicators could of course be added.

What this means is that many different kinds of evidence can often be brought to bear on both the recent and more distant history of ecosystems and landscapes to be monitored. The more diverse the kinds of evidence, the more likely they are to reinforce one another, providing historical information of great value to those concerned with monitoring future trends in ecosystems subject to natural or anthropogenic disturbances. A good example is that of Shagawa Lake in northeastern Minnesota, where the effects of cultural entrophication following the establishment of an adjacent mining settlement were elucidated using as indicators depth profiles of hematite particles, diatom and cladoceran remains, sedimentary phosphorus, and fossil pigments (Bradbury and Megard 1972; Bradbury and Waddington 1973; Gorham and Sanger 1976).

\section{Paleoecology and the surprise factor}

The long-term perspective is useful because, even with late 20th century advances in the ability to observe and model environmental processes, we are still often "surprised" by anomalies in the behavior of environmental systems. Although our remarks on surprise will focus mainly on the climate system, because of its centrality to the function of ecosystems at regional to global scales, surprises that result from century-long land use also occur. For example, the sudden catastrophic loss of submerged macrophytes observed in the Chesapeake Bay in the early 1970s (discussed earlier) was a major surprise. It was hypothesized by biologists and managers of natural resources that the reduction could represent a natural population phenomenon. The paleoecological record showed, however, that this event was a threshold response to environmental changes related to altered land use, which began two centuries prior to the sudden reduction in macrophyte beds (Brush and Hilgartner 2000). Other examples of the surprise factor with regard to marine pollution have been provided by Goldberg (1974).

Paleoclimatic information has altered theories of how the climate system operates, and this offers a strong argument for including historical perspectives in an overall monitoring plan. Our comments address the concept of environmental surprise and describe how a loosely constructed "theory of surprise" is relevant to understanding the climate system. In this context, "surprise" refers to a set of theories describing how abrupt threshold-crossing changes in environmental systems occur and why they pose problems for institutions charged with providing the means to cope with change (Conway 1948; Holling 1986; Kates and Clark 1996). Surprises result from interactions between people's expectations and the behavior of the environment, and they occur "when perceived reality departs qualitatively from expectation" (Holling 1986). Surprise confounds our expectations, entailing events that we never imagined could occur (Kates and Clark 1996). Holling (1986) emphasizes that our expectations are strongly shaped by underlying metaphors, models, and belief systems, especially fundamental concepts regarding the nature of causality, stability, and change.

The theory of surprise is particularly relevant to research on climatic variability at present because our most basic beliefs regarding the dynamics of the climate system are in a state of flux, fueled in large part by new information regarding how the climate system behaves on time scales of decades to centuries. Specifically, our expectation that the climatic system is stationary or static on that time scale has been discredited by a growing body of empirical as well as theoretical work (e.g., Mandlebrot and Wallis 1969; Mitchell 1976; Lorenz 1986). Recent compilations of climate data indicate clearly that the short instrumental record of climate (i.e., the last 50 to 100 years) does not represent a stationary record (Karl 1995; Diaz and Bradley 1995).

Evidence for climate "jumps" is not restricted to this century. Smoothed reconstructions of regional precipitation as inferred from tree-ring records indicate abrupt changes that are clearly outside the range of variability of 20th-century data, as shown in Fig. 9. The top panel is a reconstruction of winter precipitation for the southern Sierra Nevada. The lower panel is a reconstruction of annual precipitation 


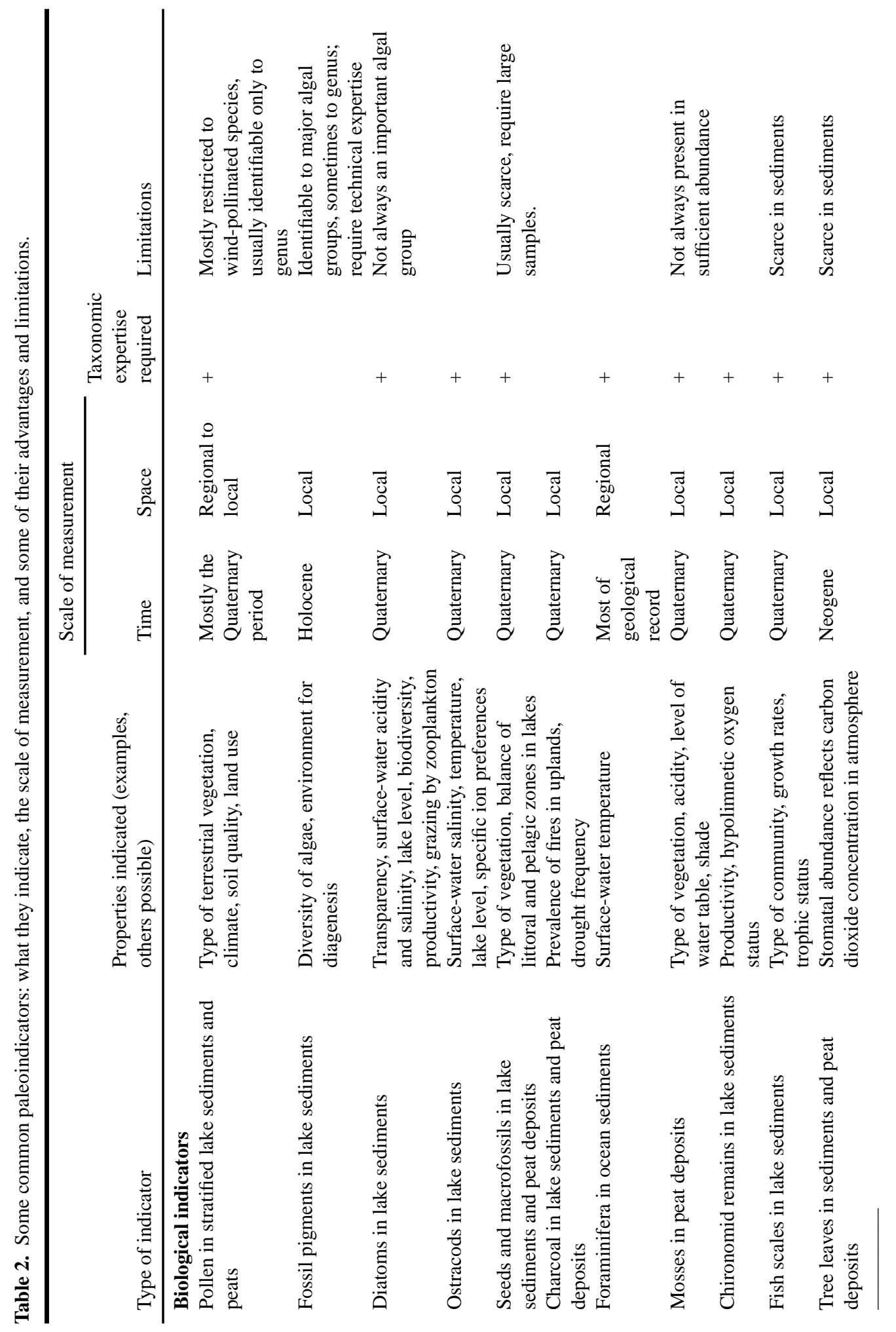




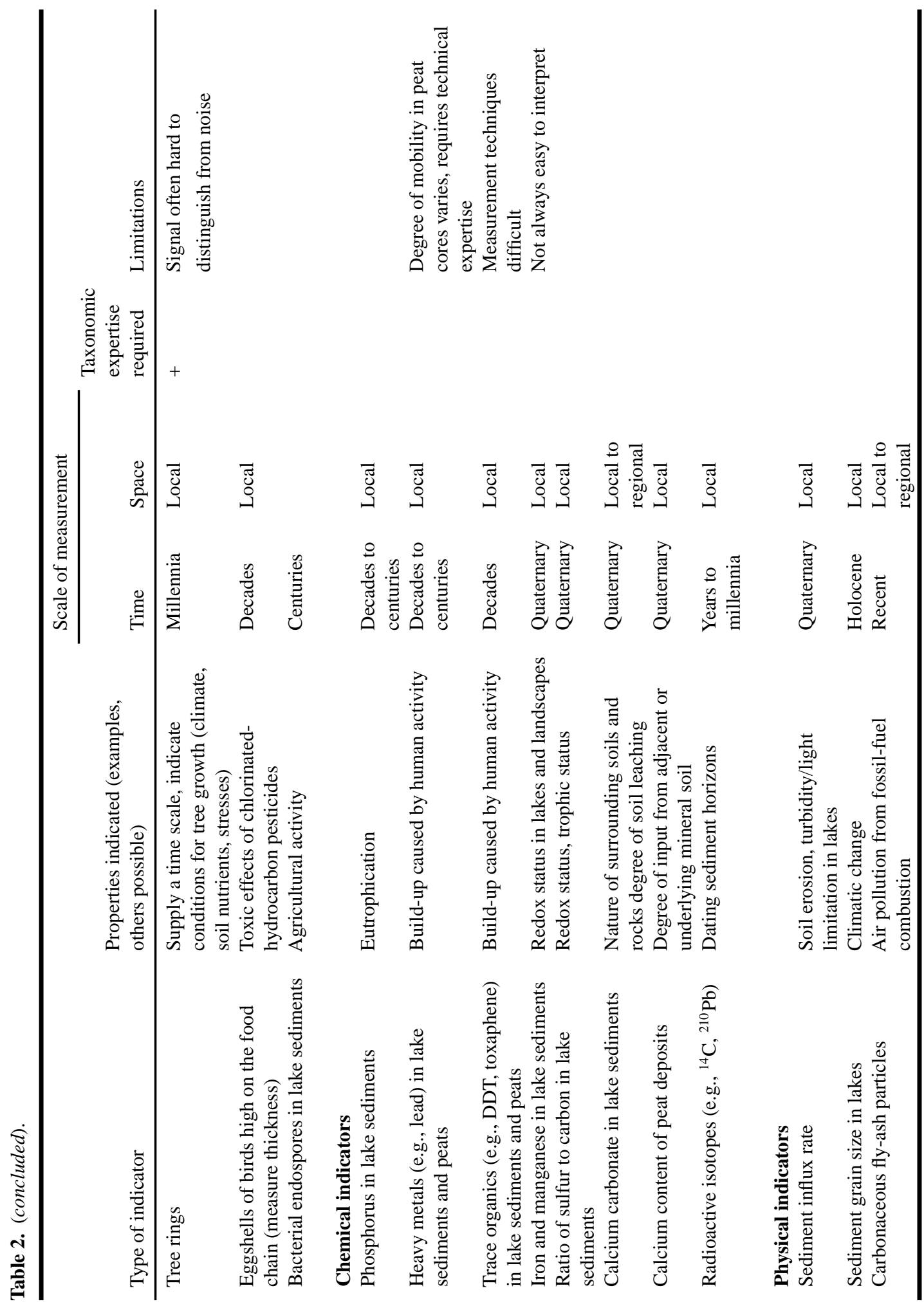


Fig. 9. Variability in precipitation (expressed as $z$ scores, i.e., number of standard deviations from the mean) from 800 AD to the present. Sierra Nevada data from Graumlich (1993), Nevada Division 3 data from Hughes and Graumlich (1996), figure modified from Hughes and Graumlich (1996).

Sierra Nevada winter precipitation (Graumlich 1993)

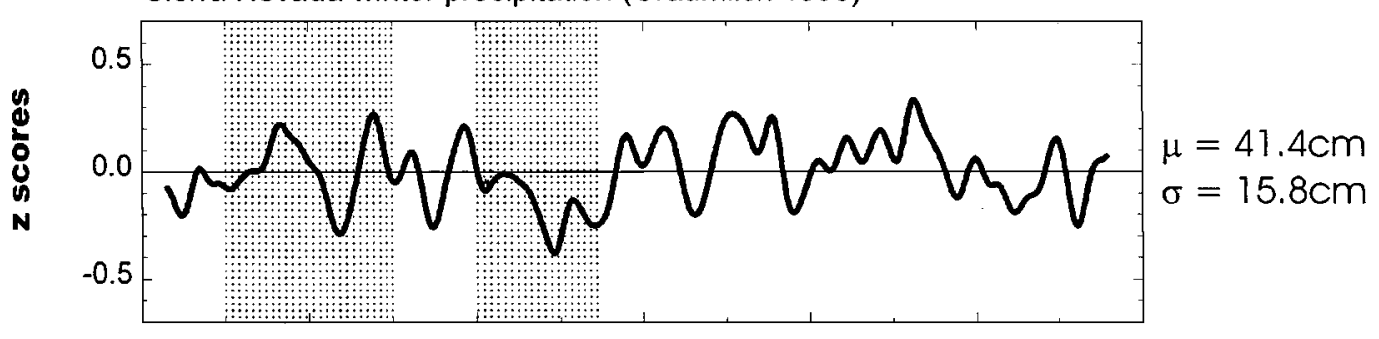

Nevada Division 3 annual precipitation (Hughes \& Graumlich 1996)

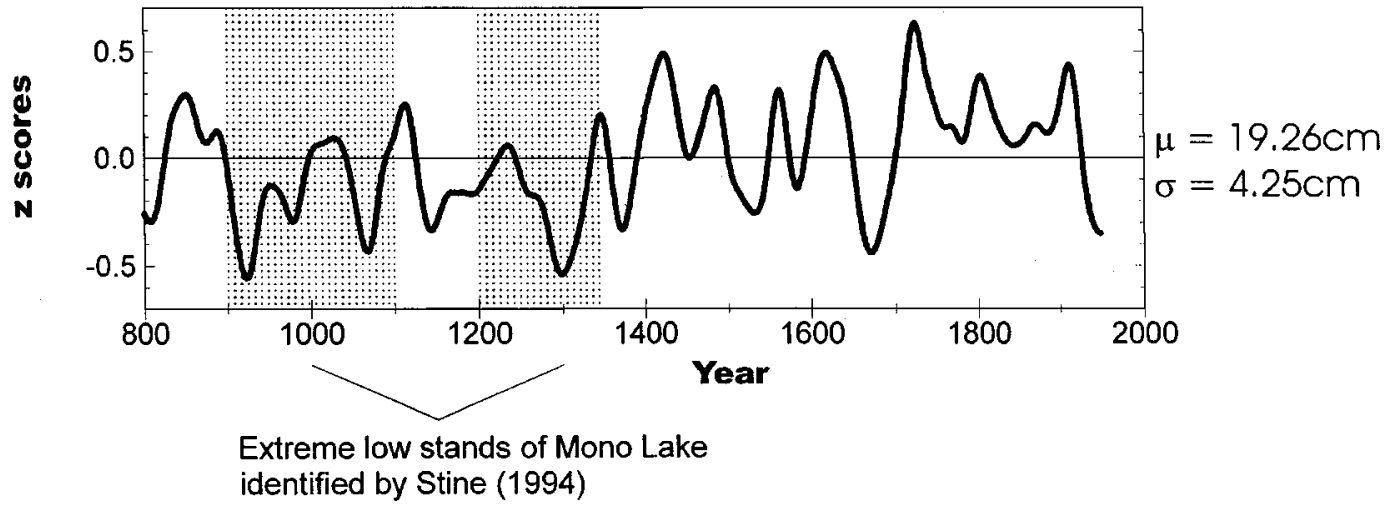

for southwestern Nevada. Corroborating evidence for multi-decadal droughts in the region, as inferred from radiocarbon-dated geomorphic events, is indicated for the periods AD 900-1100 and AD 12001350 (Stine 1994). These droughts are correlated with droughts of similar magnitude and extent over much of the western United States: from southern California, across the Colorado Plateau, and as far east as the Sand Hills of Nebraska (see references and discussion in Graumlich and Ingram 2000).

High-resolution paleoclimatic studies of Greenland ice cores indicate that mean annual temperature can change up to $10^{\circ} \mathrm{C}$ in a few years (Grootes et al. 1993; Alley et al. 1993). Furthermore, evidence from Greenland implies that rapid "jumps" in climate may be particularly characteristic of times of changing boundary conditions leading to a warmer climate (Broecker 1987; Overpeck 1996). We are not certain why such shifts occur or the degree to which, in the recent past, they represent anthropogenic changes or natural variability (National Research Council 1995). We are certain, however, that the 30-year time frame over which we define climate "normals" is not sufficient to characterize climate-related risks, especially in the case of relatively rare, extreme events.

The emerging view of the climate system is, therefore, one in which (1) nonstationary behavior (i.e., "jumps" in the system) is probable, especially in times of changing boundary conditions, and (2) decade-scale and longer-scale trends or episodes are important characteristics of the system. These new models and metaphors regarding the nature of climatic change call into question traditional approaches to monitoring climate and climate-related systems. For example, climate-related risks such as droughts or floods are usually evaluated in a probabilistic framework in which the severity of the event is framed relative to long-term "normal" conditions and (or) the intensity of previous events. Research thus focuses on reducing uncertainty associated with climate-related risks; that is, specifying 
more accurately the probability of occurrence and nature of consequences through monitoring programs. Often probabilities and the range of potential consequences are poorly known, and they are sometimes unknowable. Nevertheless, much scientific effort is aimed at reducing uncertainty regarding the probability of a given magnitude of climate-related risk, with the implicit assumption that reducing uncertainty enhances the generation of sound policies for response. This assumption may not hold, especially for climate-related hazards that are regional to global in scale (Waterstone 1993). In sum, if we think of the system as stationary, then the requisite task for monitoring is garnering a statistically appropriate data set to characterize a simple system. If we suspect that the system is nonstationary, then we have the more difficult task of anticipating "jumps" in system behavior.

Research on global change has raised the specter that increasing atmospheric trace gases and other similar globally scaled changes may result in non-linear behavior in the climate system, resulting in unanticipated climate events or "surprises." Further, the societal consequences of climatic "surprises" may take unanticipated forms because of the increasingly tight linkages among people, institutions, and environmental resources caused by increased population, consumption, and the globalization of trade. Under such circumstances, research priorities must shift from reducing uncertainty to anticipating the unexpected, using techniques based on analyses of historical and paleoecological data, techniques associated with analyses of complex systems, and other methods (Schneider et al. 1998). Further, in anticipating broad classes of "surprises" we must confront certain challenges in developing monitoring programs. Those listed by Kates and Clark (1996) include

- the need to monitor hazards not only where they are supposed to be, but also where they are not

- the way in which "outliers" (i.e., data that are at odds with expectation) are handled, recognizing that anomalies may reflect previously undetected phenomena rather than measurement error

- being open to considering complex interactions and multiple causes for observed system states and thereby minimizing errors in the attribution of cause and effect

Progress in research will of course diminish the possibility of surprises. Nevertheless, given the complexity and non-linearity of the natural world, we must continue to expect them and be prepared to deal with their consequences.

\section{Conclusions and recommendations}

It appears from the evidence described above that analyses based on paleoecological archives can be of great value in providing much needed background for the design of monitoring programs, and interpretation of resulting data, in a great variety of ecosystems subject to almost any environmental stress. Much of such information can, moreover, be acquired in no other way. In particular, paleoecological records provide long-term databases with which to compare present-day conditions and can therefore be useful in deciding on sampling frequencies for monitoring programs. Many records are spatially extensive. They also exist at different temporal scales (related in many cases to rates of sediment accumulation), are usually consistent through time, and include multiple indicators that can reinforce the conclusions from any one of them. Moreover, although paleoecological indicators are retrospective in nature, the trends established by their use can be prospective, forecasting what is likely to occur in the future unless actions are taken to change such trends.

Paleoecological measurements are not subject to errors related to different instrumentation over the years or to changes in locations of measurements from time to time. They do have their own sources of errors, but these can generally be quantified. For instance, errors in sedimentation rates and influx values owing to the imprecision of dated horizons in sediment cores and the sample size (e.g., 1- or 2-cm intervals) can be calculated using the first-order propagation of error (Benjamin and Cornell 1970). 
Apart from these kinds of errors, the general problems of interpretation outlined by Davis (1989a) and mentioned earlier must always be borne in mind.

In setting up monitoring programs, paleoecological records of ecosystems with low resistance to or resilience after disturbance are probably more significant than records of areas buffered or protected by physical or chemical conditions. Lakes on granite and quartzite are examples of ecosystems with low resistance to the stress of acid deposition and hence liable to severe acidification and biotic impoverishment. Their $\mathrm{pH}$ and alkalinity can, however, rebound quite rapidly once the stress is removed, although biological communities show mixed results, with some groups recovering rapidly and a few not at all (Schindler et al. 1991). Addition of a toxic-metal stress, as in lakes around the copper-nickel smelters at Sudbury, Ontario, slows recovery and leads to the dominance of only a few species (Havas et al. 1995) despite a rapid rebound of $\mathrm{pH}$ as shown in Fig. 2. In contrast, the upland landscape around Sudbury provides examples of low resilience following severe disturbance owing to fumigation by gaseous sulphur dioxide. There, forest ecosystems were wiped out close to the smelters (Gorham and Gordon 1960; Hutchinson and Whitby 1974) as tree, shrub, herb, and ground layers of vegetation were peeled off successively by long-continued fumigations. Once the vegetation was destroyed, erosion stripped the soil from the rocky uplands, leading to severe siltation of local streams. Neither the barren uplands nor the silted streams are likely to return to their original condition, although where some soil remains, liming and fertilization can assist recovery of the upland vegetation (Winterhalder 1996).

In the light of these conclusions we recommend that

- paleoecological indicators be given consideration, in all monitoring programs, as a means of providing long-term baseline data and also of investigating the possibility of rare "surprise" events

- paleoecological records be used, where possible, to assist in decisions on the sampling frequency and duration of a monitoring program

- multiple paleoindicators be used, where possible, as a check on one another and to reinforce the conclusions drawn from the data

\section{Acknowledgements}

This article developed out of our joint service on the Committee to Evaluate Indicators for Monitoring Aquatic and Terrestrial Environments, of the U.S. National Research Council (National Research Council 2000). It also owes much to the many friends who have kindly sent us reprints over the past several decades. We thank Jan Janssens for Fig. 6. John Tallis and an anonymous referee provided helpful criticisms.

\section{References}

Alley, R.B., Meese, D.A., Shuman, C.A., Gow, A.J., Taylor, K.C., Grootes, P.M., White, J.W.C., Ram, M., Waddington, E.D., Mayewski, P.A., and Zielinski, G.A. 1993. Abrupt accumulation increase at the Younger Dryas termination in the GISP2 ice core. Nature (London), 362: 527-529.

Anderson, T.W. 1974. The chestnut pollen decline as a time horizon in lake sediments in eastern North America. Can. J. Earth Sci. 11: 678-685.

Battarbea, R.W. 2000. Paleolimnological approaches to climate change, with special regard to the biological record. Quat. Sci. Rev. 19: 107-124.

Benjamin, J.A., and Cornell, A.C. 1970. Probability, statistics and decision for civil engineers. McGraw-Hill, New York, N.Y.

Berglund, B.E. 1986. Handbook of Holocene paleoecology and paleohydrology. Wiley, New York, N.Y. 869 p.

Bhiry, N., and Filion, L. 1996. Mid-Holocene hemlock decline in eastern North America linked with phytophagous insect activity. Quat. Res. 45: 312-320. 
Birks, H.J.B., and Birks, H.H. 1980. Pollen production, dispersal, deposition, and preservation. In Quaternary paleoecology. Edited by H.J.B. Birks and H.H. Birks. University Park Press, Baltimore, Md. pp. 177-194.

Björck, S., Fromer, B., Johnsen, S., Bennike, O., Hammarlund, D., Lemdahl, G., Possnert, G., Rasmussen, T.L., Wohlfarth, B., Hammer, D.U., and Spurk, M. 1996. Synchronized terrestrial-atmospheric deglacial records around the North Atlantic. Science (Washington, D.C.), 274: 1155-1160.

Bradbury, J.P., and Megard, R.O. 1972. Stratigraphic record of pollution in Shagawa Lake, northeastern Minnesota. Geol. Soc. Am. Bull. 83: 2639-2648.

Bradbury, J.P., and Waddington, J.C.B. 1973. The impact of European settlement on Shagawa Lake, northeastern Minnesota, U.S.A. In Quaternary plant ecology. Edited by H.J.B. Birks and R.G. West. Blackwell, Oxford, U.K. pp. 289-307.

Bradbury, J.P., and Dean, W.E. 1993. Elk Lake, Minnesota: Evidence for rapid climate change in the north-central United States. Geological Society of North America Special Paper, No. 276, 336 p.

Bradshaw, R.H.W., and Webb, T., III. 1985. Relationships between contemporary pollen and vegetation data from Wisconsin and Michigan, USA. Ecology, 66: 721-737.

Briffa, K.R. 2000. Annual climate variability in the Holocene: interpreting the message of ancient trees. Quat. Sci. Rev. 19: 87-105.

Broecker, W.S. 1987. Unpleasant surprises in the greenhouse? Nature (London), 328: 123-126.

Brubaker, L.B., and Greene, S.K. 1980. Differential effects of Douglas-Fir tussock moth and Western Spruce budworm defoliation on radial growth of grand fir and Douglas-Fir. Can. J. For. Res. 9: 95-105.

Brugam, R.B. 1978. Human disturbance and the historical development of Linsley Pond. Ecology, 59: 19-36.

Brush, G.S. 1984. Patterns of recent sediment accumulation in Chesapeake Bay (Virginia-Maryland, U.S.A.) tributaries. Chem. Geol. 44: 227-242.

Brush, G.S. 1986. Geology and paleoecology of Chesapeake Bay: a long-term monitoring tool for management. J. Wash. Acad. Sci. 76(3): 146-160.

Brush, G.S., and Brush, L.M. 1994. Transport and deposition of pollen in an estuary: a signature of the landscape. In Sedimentation of organic particles. Edited by A. Traverse. Cambridge University Press, Cambridge, U.K. pp. 34-46.

Brush, G.S., and Hilgartner, W.B. 2000. The paleoecology of submerged macrophytes in the Upper Chesapeake Bay. Ecol. Monogr. 70: 645-667.

Calcote, R. 1998. Identifying forest stand types using pollen from forest hollows. The Holocene, 8: $423-442$.

Campbell, C. 1998. Late Holocene lake sedimentology and climate change in southern Alberta, Canada. Quat. Res. 49: 96-101

Charles, D.F., Battarbee, R.W., Renberg, I., Van Dam, H., and Smol, J.P. 1989. Paleoecological analysis of lake acidification trends in North America and Europe using diatoms and chrysophytes. In Acidic precipitation, vol. 4. Edited by S.A. Norton et al. Springer-Verlag, New York, N.Y. pp. 207-276.

Charles, D.F., Smol, J.P., and Engstrom, D.R. 1994. Paleolimnological approaches to biomonitoring. In Biological monitoring of aquatic systems. Edited by S. Loeb and A. Spacie. CRC Press, Boca Raton, Fla. pp. 233-293.

Clark, J.S. 1988. Effect of climate change on fire regimes in northwestern Minnesota. Nature (London), 334: 233-235.

COHMAP Members. 1988. Climate changes of the last 18,000 years: Observations and model simulations. Science (Washington, D.C.), 241: 1043-1052.

Cole, K., and Liu, G. 1994. Holocene paleoecology of an estuary on Santa Rosa Island, California. Quat. Res. 41: 326-335.

Conway, V.M. 1948. Von Post's work on climatic rhythms. New Phytol. 47: 220-237.

Cook, E.R. 1987. The use and limitations of dendrochronology in studying effects of air pollution on forests. In Effects of atmospheric pollutants on forests, wetlands and agricultural ecosystems. Edited by T.C. Hutchinson and K.M. Meema. NATO ASI Series G: Ecological Sciences, Vol. 16, Springer-Verlag, New York, N.Y. pp. 277-290.

Cook, E.R., and Peters, K. 1981. The smoothing spline: a new approach to standardizing forest interior tree-ring width series for dendroclimatic studies. Tree-ring Bull. 41: 45-53.

Cook, E., Bird, T., Peterson, M., Barbetti, M., Buckley, B., D’Arrigo, R., Francey, R., and Tans, P. 1991. Climatic change in Tasmania inferred from a 1089-year tree-ring chronology of Huon pine. Science (Washington, D.C.), 253: 1266-1268. 
Cooper, S.R. 1995. Chesapeake Bay watershed historical land use: impact on water quality and diatom communities. Ecol. Appl. 5: 703-723.

Cooper, S.R., and Brush, G.S. 1991. Long-term history of Chesapeake Bay anoxia. Science (Washington, D.C.), 254: 992-996.

Craig, A.J. 1969. Vegetational history of the Shenandoah Valley, Virginia. Geol. Soc. Am. Special Paper 123: 283-297.

D’Arrigo, R.D., and Jacoby, G.C. 1993. Secular trends in high northern latitude temperature reconstructions based on tree rings. Clim. Change, 25: 163-177.

Davis, M.B. 1969. Climatic changes in southern Connecticut recorded by pollen deposition at Rogers Lake. Ecology, 50: 409-422.

Davis, M.B. 1973. Pollen evidence of changing land use around the shores of Lake Washington. Northwest Sci. 47: 133-148.

Davis, M.B. 1981a. Quaternary history and the stability of forest communities. In Forest succession: concepts and application. Edited by D.C. West, H.H. Shugart, and D.B. Botkin. Springer-Verlag, New York, N.Y. pp. 132-153.

Davis, M.B. 1981b. Outbreaks of forest pathogens in forest history. In Proceedings of the IV International Conference (1976-77), vol. 3. Birbal Sahni Institute of Paleobotany, Lucknow, India. pp. 216-227.

Davis, M.B. 1985. History of the vegetation on the Mirror Lake watershed. In An ecosystem approach to aquatic ecology: Mirror Lake and its environment. Edited by G.E. Likens. Springer-Verlag, New York, N.Y. pp. 53-65.

Davis, M.B. 1989a. Insights from paleoecology on global change. Ecol. Soc. Am. Bull. 70: 222-228

Davis, M.B. 1989b. Lags in vegetation response to climatic warming. Clim. Change, 15: 75-82.

Davis, M.B. 1991. Research questions posed by the paleoecological record of global change. In Global changes of the past. Edited by R.S. Bradley. UCAR Office for Interdisciplinary Studies, Boulder, Co.

Davis, M.B. 2000. Palynology after Y2K - understanding the source area of pollen in sediments. Annu. Rev. Earth Planet. Sci.28: 1-18.

Davis, M.B., Sugita, S., Calcote, R.R., Ferrari, J.B., and Frelich, L.E. 1994. Historical development of alternate communities in a hemlock-hardwood forest in northern Michigan, USA. In Large-scale ecology and conservation biology. Edited by P.J. Edwards, R. May, and N.R. Webb. Blackwell, Oxford, U.K. pp. 19-39.

DeHayes, D.H., Shaberg, P.G., Hawley, G.J., and Strimbeck, G.R. 1999. Acid rain impacts on calcium nutrition and forest health. Bioscience, 49: 789-800.

Diaz, H.F., and Bradley, R.S. 1995. Documenting natural climatic variations: how different is the climate of the twentieth century from that of previous centuries? In Natural climatic variability on decade-tocentury time scales. Edited by D.G. Martinson, K. Bruan, M. Ghil, M.M. Hall, T.R. Karl, E.S. Sarachik, S. Sorooshian, and L.D. Talley. National Academy Press, Washington, D.C. pp. 17-31.

Dixit, A.S., Dixit, S.S., and Smol, J.P. 1992. Algal microfossils provide high temporal resolution of environmental trends. Water, Air Soil Pollut. 62: 75-87.

Engstrom, D.R., Swain, E.B., and Kingston, J.C. 1985. A paleolimnological record of human disturbance from Harvey's Lake, Vermont: geochemistry, pigments and diatoms. Freshwater Biol. 15: 261-288.

Finney, B.P., Gregory-Eaves, I., Sweetman, J., Douglas, M.S.V., and Smol, J.P. 2000. Impacts of climatic change and fishing on Pacific salmon abundance over the past 300 years. Science (Washington, D.C.), 290: 795-799

Flannery, T.F. 1994. The future eaters: an ecological history of the Australian land and people. Reed Books, Chatswood.

Foster, D. 1995. Land-use history and four hundred years of vegetation change in New England. In Global land use change: a perspective from the Columbian encounter. Edited by B.L. Turner, A.G. Sal, F.G. Bernaldez, and F. di Castri. Consejo Superior de Investigaciones Cientificas, Madrid, Spain. pp. 253-319.

Fritts, H.C. 1976. Tree rings and climate. Academic Press, London, United Kingdom.

Gajewski, K. 1987. Climatic changes on the vegetation of eastern North America during the past 2000 years. Vegetatio, 68: 179-190.

Gates, W.L., and 17 others. 1975. Appendix A, Survey of past climates. In Understanding climatic change: a program for action. National Academy of Sciences, Washington, D.C. pp. 127-195. 
Goldberg, E.D. 1974. The surprise factor in marine pollution studies. Mar. Technol. Soc. J. 8: 29-34.

Gorham, E. 1957. The development of peatlands. Q. Rev. Biol. 32: 145-166.

Gorham, E. 1991. Biogeochemistry: its origins and development. Biogeochemistry, 13: 199-239.

Gorham, E., and Gordon, A.G. 1960. The influence of smelter fumes upon the chemical composition of lake waters near Sudbury, Ontario, and upon the surrounding vegetation. Can. J. Bot. 38: 477-497.

Gorham, E., and Janssens, J.A. 1992a. The paleorecord of geochemistry and hydrology in northern peatlands and its relation to global change. Suo, 43: 9-19.

Gorham, E., and Janssens, J.A. 1992b. Concepts of fen and bog re-examined in relation to bryophyte cover and the acidity of surface waters. Acta Soc. Bot. Pol. 61: 7-20.

Gorham, E., and Sanger, J.E. 1976. Fossilized pigments as stratigraphic indicators of cultural eutrophication in Shagawa Lake, northeastern Minnesota. Geol. Soc. Am. Bull. 87: 1638-1642.

Gorham, E., Lund, J.W.G., Sanger, J.E., and Dean, W.E., Jr. 1974. Some relationships between algal standing crops, water chemistry and sediment chemistry in the English Lakes. Limnol. Oceanogr. 19: 601-617.

Graumlich, L.J. 1993. A 1000-year record of temperature and precipitation in the Sierra Nevada. Quat. Res. 39: $249-255$.

Graumlich, L.J. 1994. Long-term vegetation change in mountain environments: Paleoecological insights into modern vegetation dynamics. In Mountain environments in changing climates. Edited by M. Beniston. Routledge, London, U.K. pp. 167-179.

Graumlich, L.J., and Ingram, M. 2000. Drought in the context of the last 1000+ years. In Drought, a global assessment. Edited by D.A. Wilhite. Routledge, New York, N.Y. pp. 234-242.

Grootes, P.M., Stuiver, M., White, J.W.C., Johnsen, S.J., and Jouzel, J. 1993. Comparison of the oxygen isotope records from the GISP2 and GRIP Greenland ice cores. Nature (London), 366: 552-554.

Havas, M., Woodfine, D.G., Lutz, P., Yung, K., McIsaac, H.J., and Hutchinson, T.C. 1995. Biological recovery of two previously acidified, metal-contaminated lakes near Sudbury, Ontario, Canada. Water, Air Soil Pollut. 85: 791-796.

Heinselman, M.L. 1996. The boundary waters wilderness ecosystem. University of Minnesota Press, Minn.

Hofmann, W. 1978. Analysis of animal microfossils from the Grosser Segeberger See (F.R.G.). Arch. Hydrobiol. 82: 316-346.

Holling, C.S. 1986. The resilience of terrestrial ecosystems: local surprise and global change. In Sustainable development of the biosphere. Edited by W.C. Clark and R.E. Munn. Cambridge University Press, Cambridge, U.K. pp. 292-317.

Hughes, M.K., and Graumlich, L.J. 1996. Multimillennial dendroclimatic records from the western United States. In Climatic variations and forcing mechanisms of the last 2000 years. Edited by R.S. Bradley, P.D. Jones, and J. Jouzel. NATO Advanced Studies Workshop Series. Springer-Verlag, New York, N.Y. pp. 109-124.

Hunter, M.L., Jr., Jacobson, G.L., Jr., and Webb, T., III. 1988. Paleoecology and the coarse-filter approach to maintaining biodiversity. Conserv. Biol. 2: 375-385.

Hutchinson, T.C., and Whitby, L.M. 1974. A study of airborne contamination on vegetation and soils by heavy metals from the Sudbury, Ontario copper-nickel smelters. In Trace elements in environmental health. VII. A symposium. Edited by D.D. Hemphill. University of Missouri Press, Columbia, Mo. pp. 175-178.

Jackson, S.T., Overpeck, J.T., Webb III, T., Keattch, S.E., and Anderson K.H. 1997. Mapped plant pollen and macrofossil records of late Quaternary vegetation change in eastern North America. Quat. Sci. Rev. 16: $1-70$.

Janssens, J.A., Hansen, B.C.S., Glaser, P.H., and Whitlock, C. 1992. Development of a raised-bog complex in Northern Minnesota. In Patterned peatlands of Northern Minnesota. Edited by H.E. Wright, Jr., B. Coffin, and N. Aaseng. University of Minnesota Press, Minneapolis, Minn. pp. 189-221.

Johnson, A.H. 1992. The role of abiotic stresses in the decline of red spruce in high elevation forests of the eastern U.S. Annu. Rev. Phytopathol. 30: 349-367.

Johnson, A.H., Cook, E.R., and Siccama, T.G. 1988. Climate and red spruce growth and decline in the northern Appalachians. Proc. Natl. Acad. Sci. 85: 5369-5373.

Jones, V.J., Flower, R.J., Appleby, P.G., Natanski, J., Richardson, N., Rippey, B., Stevenson, A.C., and Battarby, R.W. 1993. Paleolimnological evidence for the acidification and atmospheric contamination of lochs in the Cairngorm and Lochnagar areas of Scotland. J. Ecol. 81: 3-24.

Kansanen, P.H. 1985. Assessment of pollution history from recent sediments in Lake Vanajavesi, southern 
Finland. II. Changes in the Chironomidae, Chaoboridae and Ceratopogonidae (Diptera) fauna. Ann. Zool. Fenn. 22: 57-90.

Karl, T.R. 1995. Atmospheric observations. In Natural climatic variability on decade-to-century time scales. Edited by D.G. Martinson, K. Bruan, M. Ghil, M.M. Hall, T.R. Karl, E.S. Sarachik, S. Sorooshian, and L.D. Talley. National Academy Press, Washington, D.C. pp. 12-16.

Kates, R.W., and Clark, W.C. 1996. Environmental surprise: expecting the unexpected. Environment, 38: 6-34.

Khan, H., and Brush, G.S. 1994. Nutrient and metal accumulation in a freshwater tidal marsh. Estuaries, 17: 345-360.

Kullman, L. 1995. Holocene tree-limit and climate history from the Scandes Mountains, Sweden. Ecology, 76: $2490-2502$.

Kummel, B., and Raup, D. (Editors). 1965. Handbook of paleontological techniques. W.H. Freeman, San Francisco, Calif. pp. 852.

LaMarche, V.C., and Mooney, H.A. 1967. Altithermal timberline advance in western United States. Nature (London), 213: 980-982.

Lara, A., and Villalba, R. 1993. A 3620-year temperature record from Fitzroya cupressoides tree rings in southern South America. Science (Washington, D.C.), 260: 1104-1106.

Leavitt, P.R. 1993. A review of factors that regulate carotenoid and chlorophyll deposition and fossil pigment abundance. J. Paleolimnol. 9: 109-127.

Leavitt, P.R., and Findlay, D.L. 1994. Comparison of fossil pigments with 20 years of phytoplankton data from eutrophic Lake 227, Experimental Lakes Area, Ontario. Can. J. Fish. Aquat. Sci. 51: 2286-2299.

Lloyd, A.H., and Graumlich, L.J. 1997. Holocene dynamics of treeline forests in the Sierra Nevada. Ecology, 78: $1199-1210$.

Lorenz, E.N. 1986. The index cycle is alive and well. In the Namias Symposium. Edited by J.O. Roads. Scripps Institution of Oceanography, La Jolla, Calif. pp. 188-196.

Luckman, B.H., Briffa, K.R., Jones, B.D., and Schweingruber, F.H. 1997. Tree-ring based reconstruction of summer temperatures at the Columbia Ice-field, Alberta. The Holocene, 7: 375-389.

Mandlebrot, B.B., and Wallis, J.R. 1969. Some long-term properties of geophysical records. Water Resour. Res. 5: 321-340.

Mann, M.E., Bradley, R.S., and Hughes, M.K. 1998. Global-scale temperature patterns and climate forcing over the past six centuries. Nature (London), 392: 779-787.

Mann, M.E., Bradley, R.S., and Hughes, M.K. 1999. Northern Hemisphere temperatures during the past millennium: inferences, uncertainties, and limitations. Geophys. Res. Lett. 26: 759-762.

Martin, P.S. 1984. Prehistoric overkill: the global model. In Quaternary extinctions: a prehistoric revolution. Edited by P.S. Martin and R. Klein. University of Arizona Press, Tucson, Ariz. pp. 354-403.

McAndrews, J.H., and Boyko-Diakonow, M. 1989. Pollen analysis of varved sediment at Crawford Lake, Ontario: evidence of Indian and European farming. In Quaternary geology of Canada and Greenland. Edited by R.J. Fulton. Geological Survey of Canada, Ottawa, Ont. pp. 528-530.

Mitchell, J.M., Jr. 1976. An overview of climatic variability and its causal mechanisms. Quat. Res. 6: 481-493.

Myers, N. 1997. The rich diversity of biodiversity issues. In Biodiversity II: understanding and protecting our biological resources. Edited by M.L. Reaka Kudla, D.E. Wilson, and E.O. Wilson. Joseph Henry Press, Washington, D.C. pp. 125-138.

National Research Council. 1995. Natural climatic variability on decade-to-century time scales. National Academy Press, Washington, D.C.

National Research Council. 2000. Ecological indicators for the nation. National Academy Press, Washington, D.C.

Norton, S.A., Evans, G.C., and Kahl, J.S. 1997. Comparison of $\mathrm{Hg}$ and $\mathrm{Pb}$ fluxes to hummocks and hollows of ombrotrophic Big Heath Bog and to nearby Sargent Mt. Pond, Maine, USA. Water, Air Soil Pollut. 100: 271-286.

Odgaard, B.V. 1994. The Holocene vegetation history of northern West Jutland, Denmark. Opera Bot. No. $123,171 \mathrm{p}$.

Orson, R.A., Simpson, R.L., and Good, R.E. 1992. The paleoecological development of a late Holocene, tidal freshwater marsh of the upper Delaware River estuary. Estuaries, 15: 130-146. 
Overpeck, J.T. 1996. Warm climate surprises. Science (Washington, D.C.), 271: 1820-1821.

Overpeck, J.T., Bartlein, P.J., and Webb, T., III. 1991. Potential magnitude of future vegetation changes in eastern North America: comparisons with the past. Science (Washington, D.C.), 254: 692-695.

Pennington, W. 1986. Lags in adjustment of vegetation to climate caused by the pace of soil development: evidence from Britain. Vegetatio, 67:105-118.

Peteet, D.M., Daniels, R.A., Heusser, L.E., Vogel, J.S., Southon, J.R., and Nelson, D.E. 1993. Late-glacial pollen, macrofossils and fish remains in northeastern USA: the Younger Dryas oscillation. Quat. Sci. Rev. 12: 597-612.

Philander, S.G.H. 1990. El Niño, La Niña and the Southern Oscillation. Academic Press, San Diego, Calif. 289 p.

Rapaport, R., and Eisenreich, S.J. 1986. Atmospheric deposition of toxaphene to eastern North America derived from peat accumulation. Atmos. Environ. 20: 2367- 2379.

Ratcliffe, D.A. 1967. Decrease in eggshell weight in certain birds of prey. Nature (London), 215: 208-210.

Renberg, I. 1990. A 12,600 year perspective of the acidification of Lilla Öresjön, southwest Sweden. Phil. Trans. R. Soc. London, Ser. B, 327: 357-361.

Renberg, I., and Nilsson, M. 1992. Dormant bacteria in lake sediments as paleoecological indicators. J. Paleolimnol. 7: 127-135

Rennie, R. 1807. Essays on the natural history and origin of peat moss, I and II. Constable, Edinburgh, U.K.

Rosenzweig, M.L. 1996. Species diversity in space and time (revised edition). Cambridge University Press, Cambridge, U.K.

Schindler, D.W., Frost, T.M., Mills, K.H., Chang, P.S.S., Davis, I.J. Findlay, L., Malley, D.F., Shearer, J.A., Turner, M.A., Garrison, P.J., Watras, C.J., Webster, K., Gunn, J.M., Brezonik, P.L., and Swenson, W.A. 1991. Comparisons between experimentally, and atmospherically, acidified lakes. In Acidic deposition and its impacts. Edited by F.T. Last and R. Watling. Royal Society of Edinburgh, Edinburgh, U.K. pp. 193-226.

Schneider, S., Turner, B.L., II, and Morehouse Garriaga, H. 1998. Imaginable surprise in global change science. J. Risk Res. 1: 165-185.

Schwalb, A., Locke, S.M., and Dean, W.E. 1995. Ostracode ${ }^{18} \mathrm{O}$ and ${ }^{13} \mathrm{C}$ evidence of Holocene environmental changes in the sediments of two Minnesota lakes. J. Paleolimnol. 14: 281-296.

Smol, J.P. 1981. Problems associated with the use of "species diversity" in paleolimnological studies. Quat. Res. 15: 209-212.

Smol, J.P. 1995. Paleolimnological approaches to the evaluation and monitoring of ecosystem health: providing a history for environmental damage and recovery. In Evaluating and monitoring the health of large scale ecosystems. Edited by D.J. Rapport, C.L. Gaudet, and P. Calow. Springer Verlag, Berlin, Germany. pp. 301-318.

Smol, J.P., Walker, I.R., and Leavitt, P.R. 1991. Paleolimnology and hindcasting climatic trends. Verh. Int. Ver. Limnol. 24: 1240-1246.

Soutar, A., and Isaacs, J.D. 1969. History of fish populations inferred from fish scales in anaerobic sediments off California. California Cooperative Oceanic Fisheries Investigations Reports 13: 63-70.

Soutar, A., and Isaacs, J.D. 1974. Abundance of pelagic fish during the 19th and 20th centuries as recorded in anaerobic sediment off the Californias. Fish. Bull. 72(2): 257-273.

Steadman, D.W. 1993. Biogeography of Tongan birds before and after human impact. Proc. Natl. Acad. Sci.. 90: $818-822$.

Stine, S. 1994. Extreme and persistent drought in California and Patagonia during medieval time. Nature (London), 369: 546-549.

Stockner, J.G., and Benson, W.W. 1967. The succession of diatom assemblages in recent sediments of Lake Washington. Limnol. Oceanogr. 12: 513-532.

Sugita, S. 1998. Modelling pollen representation of vegetation. Paleoclim. Res. 27: 1-16.

Swain, A.M. 1973. A history of fire and vegetation in northeastern Minnesota as recorded in lake sediments. Quat. Res. 3: 383-396.

Swetnam, T.W. 1993. Fire history and climate change in giant Sequoia Groves. Science (Washington, D.C.), 262: 885-889.

Swetnam, T.W., and Betancourt, J.L. 1990. Fire - Southern Oscillation relations in the southwestern United States. Science (Washington, D.C.), 249: 1017-1020.

Tiffney, B.H., and Niklas, K.J. 1990. Continental area, dispersion, latitudinal distribution, and topographic 
variety: a test of correlation with terrestrial plant diversity. In Causes of evolution: a paleontological perspective. Edited by R.M. Ross and W.G. Almon. University of Chicago Press, Chicago, Ill. pp. 76-102. Tobi, D.R., Wargo, P.M., and Bergdahl, D.R. 1995. Growth response of red spruce after known periods of winter injury. Can. J. For. Res. 25: 669-681.

Van Der Burgh, J., Visscher, H., Dilcher, D.L., and Kürschner, W.M. 1993. Paleoatmospheric signatures in Neogene fossil leaves. Science (Washington, D.C.), 260: 1788-1790.

Wargo, P.M., Bergdahl, D.R., Tobi, D.R., and Olson, C.W. 1993. Root vitality and decline of red spruce. Contrib. Biol. Arborum, 4: 1-143

Waterstone, M. 1993. Adrift on a sea of platitudes: why we will not resolve the greenhouse issue. Environ. Manage. 17(2): 141-152.

Watts, W.A. 1971. Postglacial and interglacial vegetation history of southern Georgia and central Florida. Ecology, 52: 676-690.

Watts, W.A. 1979. Late Quaternary vegetation of central Appalachia and the New Jersey Coastal Plain. Ecol. Monogr. 49: 427-469.

Watts, W.A. 1980. Late Quaternary vegetation history at White Pond on the inner Coastal Plain of South Carolina. Quat. Res. 13: 187-199.

Webb, T., III. 1987. The appearance and disappearance of major vegetational assemblages: long- term vegetational dynamics in eastern North America. Vegetatio, 69: 177-187.

Whitehead, D.R. 1973. Late Wisconsin vegetational changes in unglaciated eastern North America. Quat. Res. 3: 621-631.

Whitehead, D.R. 1981. Late Pleistocene vegetational changes in northeastern North Carolina. Ecol. Monogr. 51: 451-471.

Wik, M., and Renberg, I. 1996. Environmental records of fly-ash particles from fossil-fuel combustion. J. Paleolimnol. 15: 193-206.

Winterhalder, K. 1996. Environmental degradation and rehabilitation of landscape around Sudbury, a major mining and smelting area. Environ. Rev. 4: 185-224.

Wright, H.E., Jr. 1971. Late Quaternary vegetational history of North America. In The late Cenozoic ages. Edited by K.K. Turekian. Yale University Press, New Haven, Conn. pp. 425-464.

Yuan S. 1995. Postglacial history of vegetation and river channel geomorphology in a Coastal Plain floodplain. Ph.D. dissertation, Johns Hopkins University, Baltimore, Md. 164 pp. 